\title{
INFLUENCE OF WATER POTENTIAL ON SEEDLINGS OF SOME WHEAT (Triticum aestivum L.) HYBRIDS
}

\author{
Mohamed S. Battah ${ }^{* 1}$ and E.I. El-Sarag ${ }^{2}$
}

1. Dept. Exports, Gen. Organ. Export and Import Cont., Al-Arish, North Sinai, Egypt.

2. Dept. Plant Prod., Fac. Environ. Agric. Sci., Arish Univ., Egypt.

\begin{abstract}
At germination time of some bread wheat genotypes, both dehydration caused by polyethylene glycol (PEG-6000) and salinity initiated by $\mathrm{NaCl}$ stresses have been applied at the age of the $7^{\text {th }}$ day to investigate the seedling response of $4 F_{1}$ hybrids contrary to their 7 parents. Double wetted sheets of filtering paper included in sterilized pettri dishes were the experimental medium of growing, while, weekly irrigation solutions differed conformably with treatments. Since, drought stress solution was performed with adding $200 \mathrm{~g} / \mathrm{l}$ of PEG6000 to distilled water to obtain $-0.49 \mathrm{kPa}$ of water potential, and saline solution was performed with solving $\mathrm{NaCl}$ in the distilled water to obtain $2000 \mathrm{ppm}$ level. Hoagland solution was concerned for control treatment irrigation, regardless of the first irrigation for all treatments. Observations about stomata, growth and chemical analysis have been recorded around 2 months. Analysis of variance reflected the significance and some of the hybrid ability to stress tolerance.
\end{abstract}

Key words: Bread wheat, germination, drought, salinity, stomata, growth and chemical analysis.

\section{INTRODUCTION}

By the year of 2050, more than $50 \%$ increase in production of major cereal crops is required to meet the needs for the projected population (Fahad et al., 2016). Wheat ranks the second among these cereals after rice and ahead of maize with production of about 735 million ton annually (USDA, 2015).

Germination stage is one of the most critical periods in the life cycle of plants. Under water stress, low water potential is a determining factor inhibiting seed germination (Shen et al., 1990; Wang et al., 2002). Germination was still likely to occur after 30 days period according to the hydrotime model used by Singh et al. (2013) who ended their observations of wheat grains germination after only the first 30 days.

\footnotetext{
* Corresponding author: Tel.: +201062819651

E-mail address: m_sayed_battah@yahoo.com
}

Low soil water potential limits or prevents germination and emergence of rainfed winter bread wheat (Triticum aestivum L.). Wide differences in seedling emergence among winter wheat cultivars have been reported, but few previous experiments have examined germination differences among cultivars as a function of water potential (Singh et al., 2013). Drought imposes one of commonest and most significant constraints to agricultural production, seriously affecting crop growth, gene expression, distribution, yield and quality (Yang et al., 2004; Shi et al., 2008 and 2009). In laboratory studies, seed germination as a function of water potential is often tested with soil adjusted to desired water potentials or by using polyethylene glycol (PEG) solutions (Singh et al., 2013), which effectively lowers the water potential of an aqueous solution (Lagerwerff $\boldsymbol{e t}$ al., 
1961; Williams and Shaykewich, 1969; Tingey and Stockwell, 1977). While, seeds are often placed on PEG-soaked filter papers (Sharma, 1973; Redman, 1974; Wang et al., 2005; Singh et al., 2013). PEG is an osmotic agent, which plays an important role in the regulation of mineral elements, hormones, protein metabolism and effects of signal transduction (Ross and Harper, 1972; Verslues et al., 1998).

The main function of PEG is to slow down the moisture rate of import and export seeds, which benefit to reduce membrane system injury in process of seed imbibition and repair impaired membrane system (Ma and Liang, 2005; Jiao et al., 2009). PEG and mannitol have been used by several investigators to impose water stress on plants, seeds and callus, by decreasing the osmotic potential of the growing medium (Murungu, 2011; Singh et al., 2013; Battah, 2014; El-Sarag et al., 2015). This technique has the advantage that the water potential of medium can be controlled independently of other physical conditions such as soil crusting or temperature. This can help one to understand how seeds may respond to physical conditions at planting (Murungu, 2011).

Salinization is the scourge of intensive agriculture (Mer et al., 2000; and Rahman et al., 2008). Water availability is one of the main environmental factors limiting photosynthesis and growth (Khan et al., 1984). Salinity affects seedling growth of plants (Tezara et al., 2003; Rahman and Kayani, 1988) by slow or less mobilization of reserve foods (Kayani et al., 1990), suspending the cell division, (Meiri and Poljakoff-Mayber, 1970) and injuring hypocotyls (Assadian and Miyamoto, 1987). In this regard, Munns and Tester, 2008 found that the decreased rate of growth level after an increase of soil salinity is primarily due to the osmotic effect of the salt around the roots. Datta $\boldsymbol{e t}$ al., 2009 reported the impact of salt stress under different salinity levels on five varieties of wheat.

Data showed that salinity affected the growth attributes significantly by reducing both of root and shoot growth. Mandhania et al., 2010 interested to study the effect of short term salt stress on seedlings of some salt-tolerant and salt-sensitive genotypes of wheat. They found that osmotic potential was decreased with salt stress.

Many important physiological and morphological processes such as leaf enlargement, stomatal opening and associated leaf photosynthesis can be directly affected by the reduction of leaf turgor potential, which accompanies the loss of water from leaf tissue (Jones and Turner, 1978). The morphology, anatomy and physiology as well as chemistry characteristics can being changed by the environmental factors, which can detain the growth of plant itself and reduce the speed of photosynthesis due to closure of stomata that controlled by water retention on leaves and the dehydration of cuticula (Pennypacker et al., 1990; Watanabe et al., 1991). Stomatal closure is one of the earliest responses of plants to water deficit that limits transpiration water loss and helps plants to retain water status under drought.

However, closure of stomata in turn, results in reduction of $\mathrm{CO}_{2}$ availability for photosynthetic carbon metabolism, depresses net $\mathrm{CO}_{2}$ assimilation rate and inhibits plant ability for dry matter accumulation (Chaves et al., 2009; Hajiboland et al., 2014). In this context, Alam et al. (2011) determined a negative effect of water stress on different stomatal characters in both adaxial and abaxial surfaces of flag leaf in different lines of bread wheat. While, Liley and Ludlow (1996) stated that the plasma membrane is generally protected from desiccation-induced damage by the presence of membrane-compatible solutes, such as" sugars and amino acids. 
Therefore, a link may exist between the capacity for osmotic adjustment and the degree of membrane protection from the effect of dehydration. Tas and Tas (2007) reported that there is a line between various physiological responses to drought and plant tolerance mechanisms such as high relative water content, water potential and membrane stability as well as pigment content stability. They found that membrane stability index (MSI) varied significantly between tetraploid and hexaploid wheat varieties under irrigated and water stress conditions while hexaploids were better than tetraploid.

In plants, in general, an appropriate growth strategy is key to fitness a competitive situation, so too in wheat seedlings, their growth strategy is critical to survival (Du and Huang, 2008). Ihsan et al. (2016) evaluated the potential for adaptability and tolerance of 4 wheat genotypes to an arid environment. They examined the influence of drought stress on growth indices and measured the development after 30, 45, 60 and 75 days from sowing.

Results indicated considerable reductions in crop growth rate (CGR) of all the tested genotypes due to drought stress, which also significantly diminished the leaf area duration (LAD) of all wheat genotypes. Furthermore, Guendouz et al. (2016) studied the effect of water stress and the supplementary irrigation on leaf characters. They reported that water stress reduced the specific leaf area (SLA) due to the reduction in cell division.

Several researches on physiological and biochemical changes that occur during leaf senescence (drought stress) focused on loss of photosynthetic pigments and re-absorption of mineral nutrients such as Saeidi et al. (2010) and Hajiboland (2014). Chlorophyll and cartenoides are the main photosynthetic pigments of plants, so these are good indicators of the photosynthesis capability of a plant (Guo et al., 2013).
Hereafter, Keyvan (2010), Moaveni (2011) and Abdoli et al. (2013) reported that there was decrease in total chlorophyll content and photosynthesis rate with the increase in intensity of drought stress on wheat cultivars. Moreover, Saeidi et al. (2015) indicated that water stress during the vegetative growth stage significantly decreased each of chlorophyll a, b and total chlorophyll contents.

Furthermore, data obtained by Guo et al . (2013) concerning some drought treatments caused by using PEG-6000 at different concentrations on bread wheat seedlings, suggested that wheat seedlings may initially sense high drought environments, the harmful effects of water stress on the distribution and accumulation of carbohydrates, it also was reflecting specific detrimental effects of a drought environment. It implies that there was a closed relationship between the effects of water stress on chlorophyll fluorescence parameters of wheat seedlings.

Wheat genetic improvement through such these breeding programs concerning the counteractive environmental conditions, needs to understand well how genotypes response to stresses with the interaction between them. In addition, both of evaluation and screening are necessary to obtain good information about the parents and hybrids. Breeders regularly select for desirable expression of indirect selection criteria. Accordingly, this current investigation is hypothesizes that tolerance characteristics of the tested parents will result in their hybrids. The aim of this study was to investigate seedlings response of some bread wheat (Triticum aestivum L.) populations to drought and salinity treatments during the germination stage on some morphological, biochemical and physiological indicators. 


\section{MATERIALS AND METHODS}

This study was achieved laboratorial in the academic year 2015/2016 at Faculty of Environmental Agricultural Science (FEAS), Al-Arish University (AU), North Sinai, Egypt.

\section{Genetic Materials}

The genetic materials used in this paper included seven bread wheat genotypes. These genotypes were chosen on the basis of their genetic diversity for several agronomic traits. The seven genotypes were used as crossed parents in a six population model. The name, pedigree and origin of these parental genotypes are presented in Table (1).Hence, four crosses have been derived from the mentioned before parents, whereas, only the two parents and their $F_{1 s}$ of each cross were included without their $\mathrm{F}_{2 \mathrm{~s}}$ and the two backcrosses $\left(\mathrm{Bc}_{1 \mathrm{~s}} \& \mathrm{Bc}_{2 \mathrm{~s}}\right)$ of the six populations model. While, the 4 crosses have been designed as follows:

Cross 1 = Amna-2 X Damara-6

Cross 2 = Rama-2 X Sakha 95

Cross 3 = Alshoroq-3 X Sakha 95

Cross 4 = Salah-1 X Babaga-3

\section{Methods}

\section{Sterilization}

Enough quantity of bread wheat grains from each of parents and $\mathrm{F}_{1 \mathrm{~s}}$ were sterilized by $0.1 \% \mathrm{HgCl}_{2}$ for 30 second then washed with potable water followed by distilled water.

\section{Culturing conditions}

\section{Sowing}

Sterilized grains were divided into three parts for each genotype; the first part of grains was devoted to untreated or the control treatment. In the same time, the other two parts were exposed to water potential throughout the mentioned before stress treatments. While, the experiment have been carried out with ten replications for each genotype using 20 grains sown in sterilized pettri dishes (14 cm in dimeter) containing double sheets of filtering paper, which were wetted with the irrigation solution.

\section{Incubation}

Pettri dishes were covered to save the moisture level and kept in full darkness in an incubator at $23^{\circ} \mathrm{C}$ for seven days, then exposed to the laboratory atmosphere and have been irrigated weekly with certain solutions.

\section{Irrigation}

Hoagland solution was used as the main source of the first irrigation for all treatments, which it was wetted the double filtering papers at the beginning of culturing. Hoagland solution was also used as the main source of the weekly irrigation only for the control treatment. Meantime, 2 certain solutions were caused the water potential in 2 stress treatments.

\section{Stress treatments}

The abovementioned water potential was observed in two treatments concerning both drought and salinity stresses, separately. Therefore, these two irrigation solutions of stress were irrigated the start germinated grains on the Pettri dishes by the end of the first week instead of Hoagland solution to cause stress. Drought stress solution was performed with adding $200 \mathrm{~g} / \mathrm{l}$ of polyethylene glycol 6000 (PEG-6000) to distilled water to obtain $-0.49 \mathrm{kPa}$ water potential (Michel and Kaufmanm, 1973). The saline solution was performed with solving sodium chloride $(\mathrm{NaCl})$ in distilled water to obtain $2000 \mathrm{ppm}$ level. 
Table (1): Name, pedigree and origin of the parental genotypes.

\begin{tabular}{|c|c|c|c|}
\hline No. & Name & Pedigree & Origin \\
\hline \multirow{2}{*}{1} & \multirow{2}{*}{ Amna-2 } & CHIL-1//VEE'S'/SAKER'S' & \multirow{2}{*}{ Syria } \\
\hline & & ICW99-0026-2AP-0AP-0AP-3AP-0AP & \\
\hline 2 & Damara-6 & $\begin{array}{c}\text { VEE/PJN//2*KAUZ/3/PLK70/LIRA'S'//CNO79*2/PRL } \\
\text { ICW99-0427-8AP-0AP-0AP-3AP-0AP }\end{array}$ & Australia \\
\hline \multirow{2}{*}{3} & \multirow{2}{*}{ Rama-2 } & BOOMA-2/BOCRO-4 & \multirow{2}{*}{$\begin{array}{l}\text { South } \\
\text { Africa }\end{array}$} \\
\hline & & ICW99-0351-1AP-0AP-0AP-5AP-0AP & \\
\hline 4 & Sakha 95 & $\begin{array}{l}\text { SKAUZ*2_SRMA-CMBW91MO2694P-0T0PY-7M-010Y - } \\
\text { 010M-010Y-5 }\end{array}$ & Egypt \\
\hline 5 & Alshoroq-3 & $\begin{array}{l}\text { BOCRO-4/3/MAYON'S'//CROW'S'/VEE'S' } \\
\text { ICW99-0368-18AP-0AP-0AP-22AP-0AP }\end{array}$ & Syria \\
\hline 6 & Salah-1 & $\begin{array}{c}\text { LFN/II58.57//PRL/3/HAHN/4/KAUZ/5/KAUZ/6/TOWPE } \\
\text { ICW99-0425-8AP-0AP-0AP-22AP-0AP }\end{array}$ & Syria \\
\hline 7 & Babaga-3 & $\begin{array}{c}\text { CHEN/AE.SQ//2*OPATA/3/BABAX } \\
\text { CMSS98Y00585S-040Y-0B-0MXI-0AP-0AP-8AP-0AP }\end{array}$ & Syria \\
\hline
\end{tabular}

\section{Recorded data}

Somehow mechanisms enable higher plants dealing stand against stress, principally dehydration, either they were such escaping, avoidance, tolerance or more than one of them, together, characterizations were distinguished in suitability such as that produced by Singh (1993) and Khan $\boldsymbol{e t}$ al. (2010) as to variation and genetic control, as well as that which outlined by Munns et al. (2011) concerning saline stress characterization.

Usually, seedling germination parameters could be recorded since grains were considered germinating with the emergence of the radical (2-3 $\mathrm{mm})$, which can be observed within few days until the end of the first ten days from the sowing date.

Worthwhile, these germination parameters didn't calculated in this study. Yet, characterizations at different ages of wheat seedlings were interested several main topics including determining of some physiological and chemical as well as growth analysis traits, with emphasize on some parental differences without their $F_{1}$ hybrids as an initial step under the stress conditions of PEG medium. Hereof, parental differences included some traits such as some stomatal characters, which have been recorded at the age of two months. Meanwhile, the other tested observations were previously recorded by the end of the $30^{\text {th }}$ day.

\section{Parental differences}

In the hereinabove manner, once, the performance of the seven parents only was evaluated under only drought treatment in view of some biochemical mechanisms in addition to leaf stomata and membrane stability.

\section{Stomatal characters}

Adaxial and abaxial surface stomata characteristics have been estimated at 60 days old by using impression method outlined by Mohammdy et al. (2006). Impressions were viewed with light microscope (40X objective). Observations were made on an average of 10 fields $\mathrm{mm}^{-2}$ for each leaf with a calibrated eyepiece micrometer to measure each of:

1. Stomatal frequency of adaxial leaf surface (SFAd). 
2. Stomatal frequency of abaxial leaf surface (SFAb).

3. Mean stomatal area of adaxial leaf surface (SAAd) ( $\mu \mathrm{m}$ stomata $/ \mathrm{mm}^{2}$ of leaf).

4. Mean stomatal area of abaxial leaf surface $(\mathrm{SAAb})\left(\mu \mathrm{m}\right.$ stomata $/ \mathrm{mm}^{2}$ of leaf).

\section{Membrane character}

\section{Membrane stability index (MSI) (\%)}

Leaf Membrane Stability Index (MSI) was determined at $60^{\text {th }}$ day according to the method of Premachandra et al. (1994) as modified by Sairam (1994). Leaf stripes $(0.2 \mathrm{~g})$ of uniform size were taken in test tubes containing $10 \mathrm{ml}$ of double distilled water in two sets. Test tubes in one set were kept at $40^{\circ} \mathrm{C}$ in a water bath for $30 \mathrm{~min}$ and electrical conductivity of the water containing the sample was measured $\left(C_{1}\right)$ using a conductivity bridge. Test tubes in the other set incubated at $100 \mathrm{C}^{\circ}$ in the boiling water bath for $15 \mathrm{~min}$ and the electrical conductivity was measured as above $\left(\mathrm{C}_{2}\right)$. MSI was calculated using the formula given below:

$\mathrm{MSI}=\left(1-\mathrm{C}_{1} / \mathrm{C}_{2}\right) \times 100$

\section{Biochemical mechanisms}

\section{Abscisic acid (ABA) accumulation (mg/g fresh weight)}

The ABA content in the leaves was estimated at $60^{\text {th }}$ day using HPLC. Weighed leaves were thoroughly extracted in acetone containing $\quad 0.1 \%$ butylhydroxytoluene (Sharma et al., 2002). The extract was centrifuged at $5000 \mathrm{xg}$ for $5 \mathrm{~min}$ at $4 \mathrm{C}^{\circ}$. The supernatant was filtered through a $30 \mu \mathrm{m}$ syringe filter, and $10 \mu \mathrm{l}$ of the filtrate were used for HPLC analysis.

The separation and quantitative estimation were carried out using a HPLC system (Perkin Elmer series $200 \mathrm{LC}$ and UV/VIS detector 200 LC, USA) equipped with a 5 $\mu \mathrm{m}$ column (Spheri-5 RP-18, $220 \times 4.6 \mathrm{~mm}$, Brownlee). The solvent used was acetonitrile/water (26:74) run isocratically.
The detector was set at $440 \mathrm{~nm}$ for the integration of peak areas after calibration with the external standard ABA.

\section{Catalase (CAT) enzyme activity}

Determination of antioxidant enzyme activity of catalase (units/mg of protein) in the leaves sample estimated by the method as described by Beers and Sizer, 1952. Catalase activity level was determined by following the decrease in absorbance at 240 $\mathrm{nm}$ for $3 \mathrm{~min}$ by using spectrophotometer.

\section{Growth analysis}

Henceforth, the experimental design will be consisted of the 7 bread wheat parents and their $4 \mathrm{~F}_{1}$ hybrids. Measurements were recorded at 30-37 days old under the dehydration conditions as follows:

1. Crop growth rate $(\mathrm{CGR})=\mathrm{NAR} X \mathrm{XAI}$ (g. dry matter $/ \mathrm{m}^{2}$ of land/day)

NAR: net assimilation rate ( $\mathrm{g}$ dry matter/ $\mathrm{dsm}^{2} \mathrm{LA} /$ week) (on LA basis during one week)

$-\mathrm{NAR}=\frac{\mathrm{W} 2-\mathrm{W} 1}{\mathrm{LA} 2-\mathrm{LA1}} \times \frac{\text { Loge LA2 }- \text { Loge LA1 }}{\mathrm{T} 2-\mathrm{T} 1}$

$\mathrm{W}_{1}$ : Leaf dry weight at week begging $\left(\mathrm{T}_{1}\right)$

$\mathrm{W}_{2}$ : Leaf dry weight at the week end $\left(\mathrm{T}_{2}\right)$

$\mathrm{LA}_{1}$ : Leaf area / plant at $\mathrm{T}_{1}$

$\mathrm{LA}_{21}$ : Leaf area / plant at $\mathrm{T}_{2}$

Loge: Nabarian $\log =2.303 \times \log _{10}$

LAI: Leaf area index.

- LAI $=\frac{\text { Leaf area } / \text { plant for one surface }}{\text { Occupied soil area } / \text { plant }}$

Where:

$\mathrm{LA}=$ Maximize length $\mathrm{X}$ maximum widthX0.75

2. Leaf area duration (LAD)

Where:

$\mathrm{LAD}=\left(\mathrm{LA}_{2}-\mathrm{LA}_{1}\right) X\left(\mathrm{~T}_{2}-\mathrm{T}_{1}\right)\left(\mathrm{cm}^{2} /\right.$ week $)$

3. Specific leaf area $(\mathrm{SLA})=\mathrm{LA} / \mathrm{Lw}\left(\mathrm{cm}^{2} /\right.$ $\mathrm{mg})$ 
Where:

$\mathrm{LA}=$ Leaf area

$\mathrm{Lw}=$ Leaf weight

4. Fresh/dry weight $(F W R)=F w / W$

Where:

Fw: Plant fresh weight

W: Plant dry weight

5. Root - weight ratio $(\mathrm{RWR})=\mathrm{Rw} / \mathrm{W}$

Where: Rw: Root dry weight / plant.

\section{Chemical analysis}

Similarly and hitherto, seven parents and their four $F_{1}$ hybrids have been included. Determining was done by the age of 30 days per seedling. Nevertheless, observations were recorded since salinity stress was added beside the stress of drought contrary the control.

\section{Plant pigments $\left(\mathrm{mg} \mathrm{g}^{-1} \mathrm{FW}\right)$}

Chlorophyll a, b, total chlorophyll and total carotenoids were determined according to the method reported by Lochtenthaler (1987). Since, leaves sample $(0.5 \mathrm{~g})$ were extracted with $80 \%$ acetone and absorbance of supernatants measured spectrophotometrically.

1. Chlorophyll a was determined at wave length $663 \mu \mathrm{m}$.

2. Chlorophyll $\mathrm{b}$ was determined at wave length $645 \mu \mathrm{m}$.

3. Total chlorophyll was determined at wave length $652 \mu \mathrm{m}$.

4. Total carotenoids were determined at wave length $450 \mu \mathrm{m}$.

\section{Total carbohydrates ( $\left.\mathrm{mg} \mathrm{g}^{-1} \mathrm{FW}\right)$}

Concentration of total carbohydrates was determined in the dried leaves, using the method described by Herbert et al. (1971). Five $\mathrm{ml}$ of $67 \%$ sulphuric acid were added to a known weight of the matter $(0.1 \mathrm{~g})$ in a test tube. 6 hours later, the volume was completed to $100 \mathrm{ml}$ with distilled water and the solution was filtered.
One $\mathrm{ml}$ of the filtrate was pipetted into a test tube and an aqueous phenol solution ( $1 \mathrm{ml} \mathrm{5 \% )}$ was added to the solution and followed by concentrated $\mathrm{H}_{2} \mathrm{SO}_{4}(5 \mathrm{ml})$ from a fast delivering pipette. Measurements of the color intensity have been taken by using spectrophotometer at $490 \mu \mathrm{m}$ and content was calculated by a standard curve of glucose.

\section{Total phenolic content (TPC) $\left(\mathrm{mg} \mathrm{g}^{-1}\right.$ FW)}

Determination was done by using the folin-ciocalteau method of Singleton and Rossi, (1965) which modified by Gao et al. (2002) as described previously by Beta $\boldsymbol{e t}$ al., 2005. Briefly, samples (200 mg) were extracted with acidified methanol $(\mathrm{HCl} /$ methanol/water, 10:80: 10, $V / V)(4 \mathrm{ml})$ at room temperature for $2 \mathrm{~h}$. The obtained extracts were oxidized with folin-ciocalteau reagents, and the reaction mixture was neutralized with sodium carbonate. The mixture was incubated at room temperature for $90 \mathrm{~min}$, and its absorbance was measured at $725 \mathrm{~nm}$. Acidified methanol was used as the blank. Ferulic acid was used as the standard, and results are expressed as ferulic acid equivalents per gram.

Nitrogen, phosphorus and potassium (NPK) content (mg/g FW)

The total nitrogen $(\mathrm{N})$ concentration was determined by using the modified method of micro-Kjeldahel as described by Peach and Tracy (1956).

Phosphorus $(\mathrm{P})$, determination was done spectrophotometrically after digestion of plant material in sulphuric acid and hydrogen peroxide by Mo-blue method (Jackson, 1973).

Potassium (K) was determined using flame photometer according to Chapman and Partt (1961). Consequently, records have been calculated from a standard curve of potassium dihydrogen phosphate. 


\section{Statistical Analysis}

Records were subjected to analysis of variance via randomized complete design according to the method outlined by Steel and Torrie (1980). Least significant difference (LSD) method at confidence intervals of 0.95 was used to compare means of each treatment, genotypes and their interaction. Computations were fulfilled conformably with the MSTAT computer program package.

\section{RESULTS AND DISCUSSION}

\section{Parental Differences}

According to data illustrated in Table 2, it is clear that analysis of variance indicated that stomatal traits, abscisic acid and catalase concerning the 7 parents of bread wheat, which have been evaluated in this study, were varied significantly or high significantly between and within treatments as well as their interaction. While, there was no significance in MSI.

\section{Effect of water stress on stomatal traits and membrane stability index (MSI)}

Stomatal characters such as stomatal frequency and area of each adaxil and abaxil surfaces: SFAd, SFAb, SAAd and SAAb were illustrated in Figs. 1, 2, 3 and 4. Water deficit stress treatment increased the range limits of these studied traits considerably from $35.00-70.67$ under the control conditions, to 40.33 - 78.00 under the stressed conditions, which have been recorded by Babaga-3 and Sakha-95 parents, respectively; from $28.00-60.33$ to $34.67-71.33$, from $50960.22-68120.74$ ( $\mu \mathrm{m}$ stomata $/ \mathrm{mm}^{2}$ of leaf) to $53813.77-$ 70006.23 ( $\mu \mathrm{m}$ stomata $/ \mathrm{mm}^{2}$ of leaf), and from 49006.82 - 67053.07 ( $\mu \mathrm{m}$ stomata/ $\mathrm{mm}^{2}$ of leaf) to $52078.11-69130.26(\mu \mathrm{m}$ stomata $/ \mathrm{mm}^{2}$ of leaf) by the same parents under the same conditions, respectively.

It is of interest to note that each of stomatal frequency and stomatal area on the adaxial surface were greater than those on the abaxial surface. Meanwhile, membrane stability index (MSI) in Fig. 5 as a physiological character was varied significantly from $51.00 \%$ which recorded by Banaga-3 to $78.33 \%$ which recorded by Sakha-95under the control condition and from $57.33 \%$ to $92.00 \%$ under stress, respectively.

Stomatal conductance may be influenced under water deficit condition via changes in leaf-water potential and via metabolic changes in the leaf. There is evidence for non-hydraulic root-to-shoot communication on soil water status, which causes stomata to close without changes in water potential and turgor of leaf (Gollan et al., 1992).

Table (2): Analysis of variance for stomata, MSI, ABA and CAT of the tested droughtaffected wheat parents.

\begin{tabular}{|c|c|c|c|c|c|c|c|c|}
\hline \multirow[t]{2}{*}{ SOV } & \multirow[t]{2}{*}{ d.f } & \multicolumn{7}{|c|}{ Mean square } \\
\hline & & SFAD & SFAB & $\begin{array}{c}\text { SAAD } \\
\left(\mu \mathrm{m} \text { stomata } / \mathbf{m m}^{2}\right)\end{array}$ & $\begin{array}{c}\mathrm{SAAB}(\mu \mathrm{m} \\
\left.\text { stomata } / \mathrm{mm}^{2}\right)\end{array}$ & $\begin{array}{l}\text { MSI } \\
\text { (\%) }\end{array}$ & $\begin{array}{c}\text { ABA (mg/g } \\
\text { fresh weight) }\end{array}$ & $\begin{array}{l}\text { CAT (g dry } \\
\text { matter/m²) }\end{array}$ \\
\hline Treatments (T.) & 1 & $564.67^{* *}$ & $688.10^{* *}$ & $7642622774.75^{* *}$ & $58336569.51^{*}$ & $1710.10^{\mathrm{ns}}$ & $18946.93^{* *}$ & $0.0001^{* *}$ \\
\hline Genotypes (G.) & 6 & $891.36^{* *}$ & $915.33^{* *}$ & $77754182528.54^{* *}$ & $237035338.83^{* *}$ & $743.00^{\mathrm{ns}}$ & $280.76^{* *}$ & $0.0001^{* *}$ \\
\hline T. X G. & 6 & $13.50^{* *}$ & $10.26^{* *}$ & $71992814867.10^{* *}$ & $20346869.57^{*}$ & $39.10^{\mathrm{ns}}$ & $234.52^{* *}$ & $0.0001^{* *}$ \\
\hline Error & 28 & 1.83 & 1.21 & 3023571.43 & 7444736.55 & 0.67 & 0.057 & 0.0001 \\
\hline Total & 41 & & & & & & & \\
\hline C.V (\%) & & 2.5 & 2.34 & 1.72 & 4.72 & 1.19 & 0.88 & 0.36 \\
\hline Mean \pm STDEV & & $54.14 \pm 12.14$ & $47.10 \pm 12.37$ & $101307.17 \pm 154208.70$ & $54817.13 \pm 6646.26$ & $68.33 \pm 12.52$ & $27.35 \pm 23.19$ & $0.004 \pm 0.0005$ \\
\hline
\end{tabular}

STDEV; standard deviation, *; significant at 0.05 level of probability, ${ }^{* *}$; significant at 0.01 level of probability and ns; not significant. 

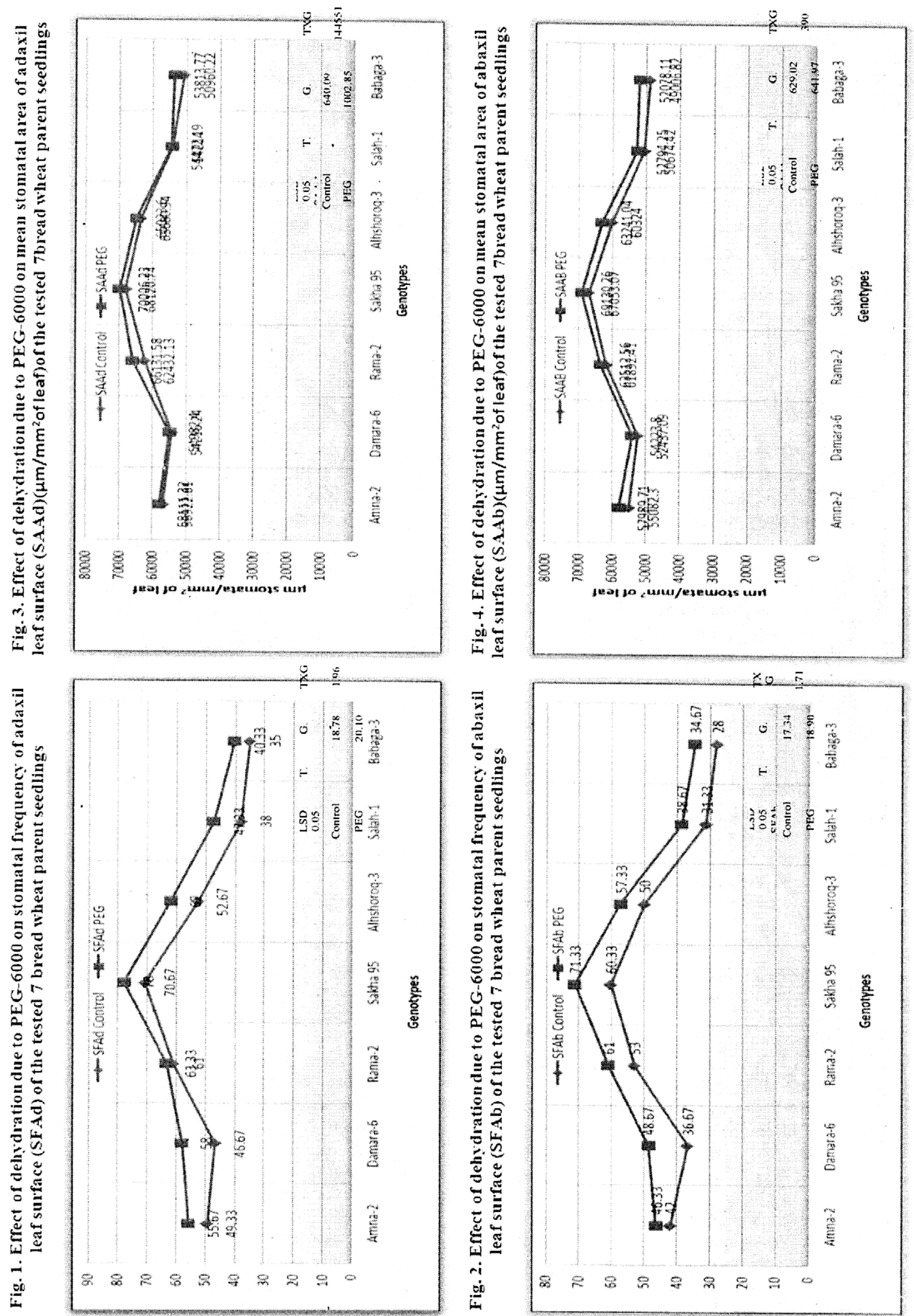
Furthermore, Comic (2000) concluded that the low rate of photosynthesis, as a result of water stress, was partially due to the stomatal closing, as the reduction of stomatal conductance is the most effective may be reduced water loss, bur acts as a burrier against the $\mathrm{CO}_{2}$ diffusion to the photosynthetic cells, which results in the reduction of $\mathrm{CO}_{2}$ concentration inside the leaves and therefore reduction photosynthesis rate. In addition, plant survival depends on maintaining a positive turgor, which is indispensable for expansion growth of cells and stomatal opening (Zhu, 2003). In this context, Sari et al. (2015) attributed the differences of stomata density and leaves thickness to the differences in ability to absorb the nutrients and to water evaporation as well as to sunlight intensity to the palisade cells.

\section{Effect of water stress on abscisic acid} (ABA) and catalase (CAT)

For the chemical analysis, from Figs. 6 and 7, it could be observed that each of abscisic acid (ABA) and catalase (CAT) increased significantly due to water deficit stress. Hereinafter, the mentioned before characters increased concerning the superior parent Babaga-3 from 7.99 (unit/mg protein) and 0.00477 (unit $/ \mathrm{mg}$ protein) to 63.41 (unit/mg protein) and 0.00507 (unit/ $\mathrm{mg}$ protein), respectively.

Yoshiba et al. (1997) announced that one of the mechanisms that were found in plant at adaptation processes is the accumulation of some components such as abscisic acid for reducing the cell potential osmotic pressure without limiting the function of enzymes. Our results are in accordance with results of Bakalova $\boldsymbol{e t} \boldsymbol{a l}$. (2004) and Csiszar et al. (2005), who were obtained a similar trend. The role of ABA in plant growth and development is multifunctional; it is involved in stomatal function, seed development and germination, and the plant's responses to water deficit, salinity and cold stresses (Hong and Bary,
1992). Synthesis of abscisic acid increases the activity of $\mathrm{RN}_{\mathrm{ase}}$ (Datta et al., 2009). Many studies confirmed a high amount of the plant stress hormone ABA as a result of increased water stress, where it plays an important role in the organization of plant responses to water stress (Davies and Zhang, 1991).

Under intense water stress, the concentration of ABA in plants increases, which triggers a number of processes starting from decrease in turgor pressure, decline in cellular expansion then stomatal closure to reduce water loss in leaves (Thompson et al., 1997). The results in the present study did not differ from what has been reported before that water stress causes ABA accumulation in stressed plants (Unyayar et al., 2004). All parents in this study showed an increase in ABA. Abscisic acid is a plant hormone that is also accumulated in plants under stresses conditions. It enables the plant to overcome abiotic stresses, such as water deficit, cold, salt and wounding (Morgan, 1984; Finkeistein et al., 2002).

Priming seeds can increase free radical scanenging enzymes such as catalase (CAT) in seeds (Chiu et al., 1995; Chang and Sung, 1998; Afzal et al., 2006). Oxidative injury at the cellular level because of water stress is a major cause of crop damage. Genotypes respond differentially to such stresses because of variations in their antioxidant systems (Balouchi, 2010).

\section{Effect of Water Stress on Growth Analysis}

Table 3 obviously referred to highly significance between and within treatments in all characteristics of growth analysis for the 11 bread wheat genotypes ( 7 parents and their $4 \mathrm{~F}_{1}$ hybrids), except leaf area duration which exhibited insignificant genotypic differences. Moreover, analysis of variance indicated that there were insignificant differences regarding to the interaction of treatments and genotypes. 

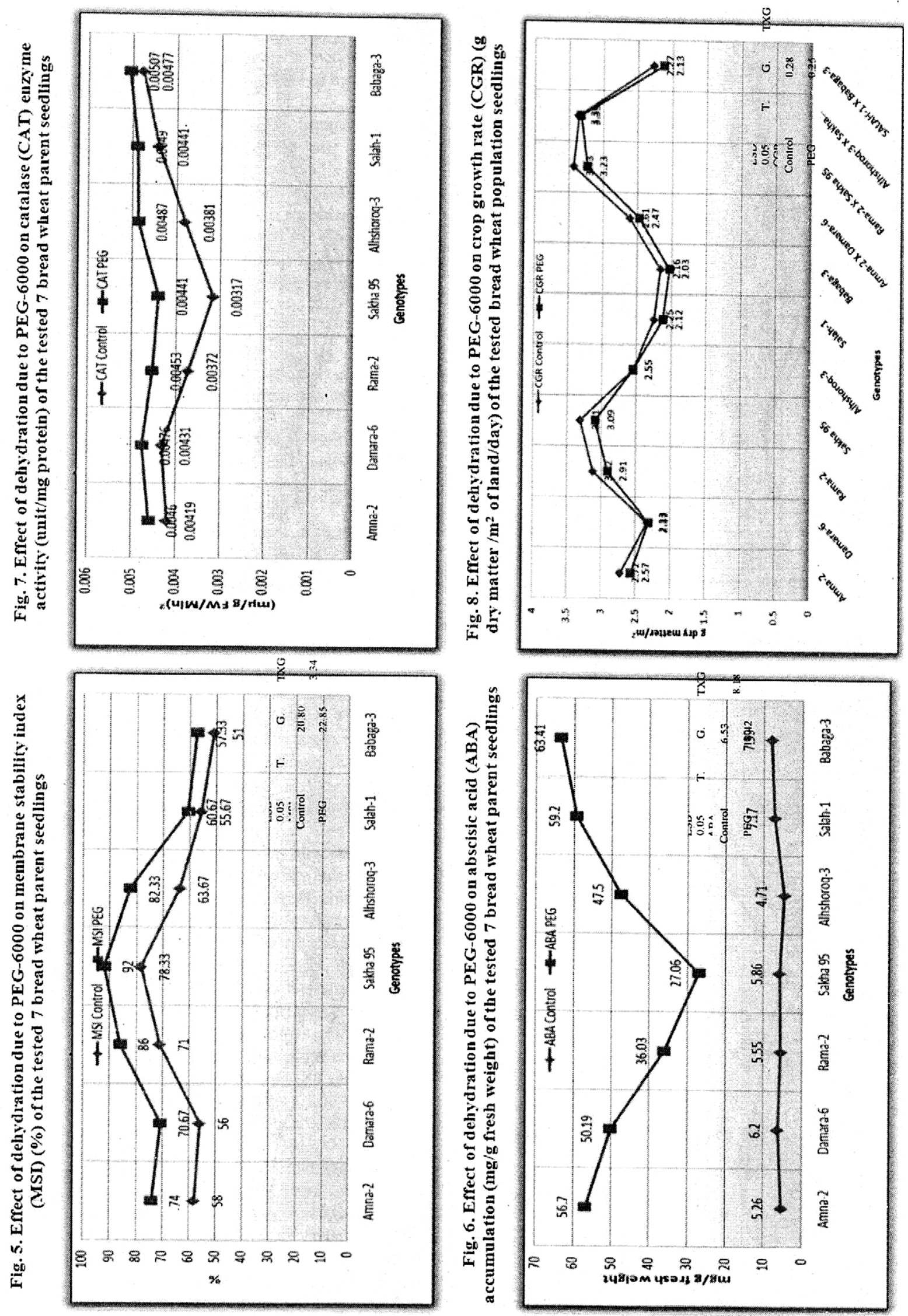
Table (3): Analysis of variance for growth analysis characters of the tested bread wheat parents and their $F_{1 s}$ influenced by dehydration

\begin{tabular}{|c|c|c|c|c|c|c|}
\hline \multirow[t]{2}{*}{ SOV } & \multirow[t]{2}{*}{ d.f } & \multicolumn{5}{|c|}{ Mean square } \\
\hline & & $\begin{array}{c}\mathrm{CGR}\left(\mathrm{x10}^{-3}\right)(\mathrm{g} \text { dry } \\
\left.\text { matter } / \mathrm{m}^{2} \text { of land/day }\right)\end{array}$ & $\begin{array}{c}\text { LAD } \\
\left(\mathrm{cm}^{2} / \text { week }\right)\end{array}$ & $\begin{array}{c}\text { SLA } \\
\left(\mathrm{cm}^{2} / \mathrm{mg}\right)\end{array}$ & FWR & RWR \\
\hline Treatments (T.) & 1 & $0.26^{* *}$ & $336199.76^{* *}$ & $141.15^{* *}$ & $2.23^{* *}$ & $0.0001^{* *}$ \\
\hline Genotypes (G.) & 10 & $1.34^{* *}$ & $6404030.38^{\text {ns }}$ & $1071.25^{* *}$ & $0.56^{* *}$ & $0.0001^{* *}$ \\
\hline T. X G. & 10 & $0.009^{\mathrm{ns}}$ & $14683.98^{\mathrm{ns}}$ & $4.53^{\mathrm{ns}}$ & $0.02^{\mathrm{ns}}$ & $0.0001^{\mathrm{ns}}$ \\
\hline Error & 44 & 0.024 & 17594.19 & 4.24 & 0.02 & 0.0001 \\
\hline Total & 65 & & & & & \\
\hline C.V (\%) & & 5.83 & 4.24 & 6.92 & 7.3 & 4.53 \\
\hline Mean \pm STDEV & & $2.67 \pm 0.48$ & $3129.49 \pm 1002.29$ & $29.75 \pm 13.06$ & $2.01 \pm 0.37$ & $0.031 \pm 0.006$ \\
\hline
\end{tabular}

STDEV: standard deviation, *; significant at 0.05 level of probability, ${ }^{* *}$; significant at 0.01 level of probability and ns; not significant.

\section{Crop growth rate (CGR) (g dry matter/ $\mathrm{m}^{2} /$ day)}

It is obvious from Fig. 8 that there were significant differences among the evaluated bread wheat population. It can be observed that water stress decreased the crop growth rate for all genotypes, except the two parents Damara-6 and Alshoroq-3 which did not affected. In this regard, the hybrid Rama-2 X Sakh-95 gave the highest crop growth rate $3.43 \times 10^{-3}$ (g dry matter $/ \mathrm{m}^{2} /$ day) concerning the well-watered plants, while, the hybrid Alshoroq-3 X Sakha-95 recorded the highest value $3.33 \times 10^{-3}$ ( $\mathrm{g}$ dry matter $/ \mathrm{m}^{2} /$ day) under the stressed conditions.

Meanwhile, water deficit treatment decreased the lowest limit of the crop growth rate which obtained by the parent Babaga-3 from $2.16 \times 10^{-3}$ (g dry matter $/ \mathrm{m}^{2}$ of land/day) under control treatment to $2.03 \times 10^{-3}$ (g dry matter $/ \mathrm{m}^{2}$ of land/day).

The mechanisms by which the water stress affects the photosynthesis process is not clearly understood yet, but the stomatal closing is one of the most important reasons for the low rates of photosynthesis in plants suffering from water stress (De Souza et al., 2005).
It is well established fact that $\mathrm{Na}$ is a toxic element whose higher concentration disturbs the different metabolic activities. The varieties which are successful in retaining the $\mathrm{Na}$ in root are tolerant.

It is well established fact that the plant infrastructure is decided by the growth parameters such as, leaf area duration (LAD), crop growth rate (CGR), net assimilation rate (NAR) and specific leaf area (SLA). This concept not only involves the final crop yield and its components, but also probes into the physiological events that have occurred early in the growth stages causing variation in yield potential (Akram, 2011).

\section{Leaf area duration (LAD) $\left(\mathrm{cm}^{2} /\right.$ week)}

From the results illustrated in Table 3 and Fig. 9, it is remarked that water deficit stress decreased leaf area duration significantly, and there were insignificant differences among the studied bread wheat genotypes. Ranges of 2.094-4.982 and 2.016-4.420 ( $\mathrm{cm}^{2} /$ week $)$ were estimated under each of watered and water deficit cultivation conditions, respectively. 

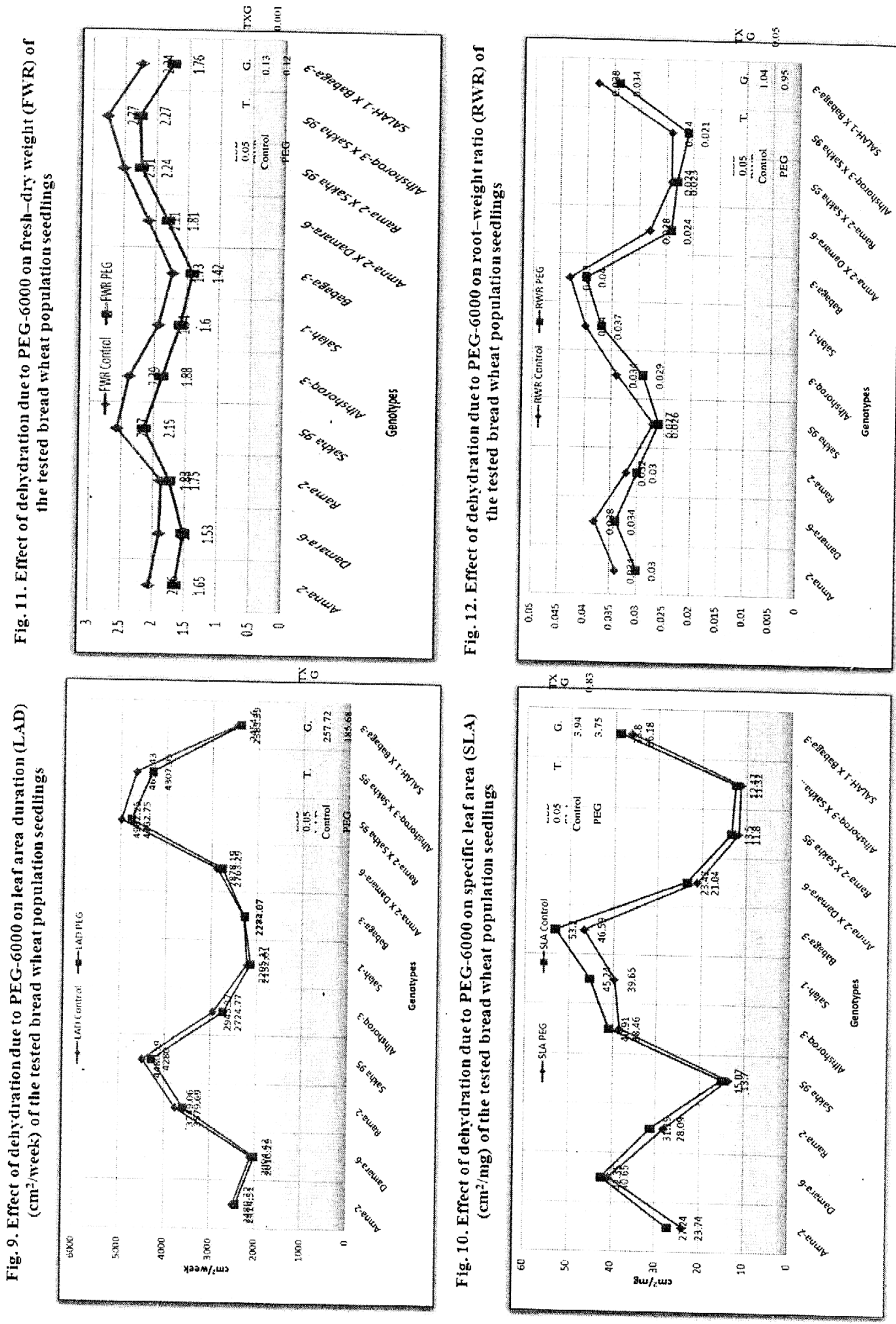
Whereas, the two lowest limits obtained by the same parent Damara-6, while the highest limits recorded by the hybrid Rama2 X Sakha-95 under normal conditions and by the parent Sakha-95 under the water deficit treatment. Leaf area duration (LAD) is a useful growth parameter not only in depicting the efficiency of photosynthetic system, but also in showing a linear relationship with accumulation of dry matter (Chetti and Sirohi, 1995).

Growth parameters such as CGR indicate the development of crop in a logical sequence and elucidate the causes for differences in yield through the events that have occurred earlier in the growth.

CGR is influenced by LAD, leaf photosynthetic rate and leaf angle and is an index of the light intercepted. Net assimilation rate (NAR) refers to a capacity of green leaves to produce dry matter and it depends on leaf area and the rate of photosynthesis. Leaves play crucial role to improve crop physiological functions and status of crops.

Leaf area duration in this regard is of prime importance as it strongly affects duration of photosynthesis. Crop productivity is directly impacted by leaf area duration maximum leaf area duration and index led to increased dry matter accumulation and yield of crop under environmental variability (Ozalkan et al., 2010).

\section{Specific leaf area (SLA) $\left(\mathrm{cm}^{2} / \mathrm{mg}\right)$}

Fig. 10 obviously shows significant differences among genotypes with a respect to the specific leaf area.

In common, water stress reduced range of the SLA from $12.47-53.20\left(\mathrm{~cm}^{2} / \mathrm{mg}\right)$ to $11.32-46.59\left(\mathrm{~cm}^{2} / \mathrm{mg}\right)$ which recorded by the hybrid Alshoroq-3 X Sakh-95 and the superior parent Babaga-3 concerning the lowest and the highest values under normal and water deficit conditions, respectively.

Various trends of response by such decrease or by increase in SLA under drought stress have been reported by several studies, interpretations also differed concerning the measuring of leaf thickness depending upon SLA. Decreasing trend in bread wheat stated by Ahmed et al. (2014).
Since, water stress may reduce the turgor pressure and hence cell expansion, resulting in approximately the same dry mass being contained within a smaller leaf area, thus raising density (Hsiao, 1973; Rascio et al., 1990).

\section{Fresh-dry weight (FWR)}

Significant differences have been recorded among population genotypes and between treatments due to water stress treatment contrary to un-treated plants regarding fresh weight-dry weight as described from Fig. 11. Water deficit stress decreased FWR from 1.73 to 1.42 concerning the lowest limit of variation which obtained by Babaga-3, furthermore, the highest limit which recorded by the hybrid Alshoroq-3 $\times$ Sakha-95 decreased from 2.77 under normal culture to 2.27 due to water deficit stress.

It is very difficult to account for yield variation in terms of growth and development, since it involves the effect of both intrinsic and extrinsic factors in all the physiological processes of plant. Various empirical relationships describe the connections between the end point of a long chain of interdependent processes in the environment and the plant (Watson, 1952).

\section{Root-weight ratio (RWR)}

Curves which illustrated in Fig. 12 obviously reflect that water stress treatment affected root-weight ratio negatively and significantly. Results are indicating that the used bread wheat genotypes also varied considerably under both control and polyethylene glycol treatment. Under normal germination conditions, the highest ratio of root-weight was 0.043 obtained by Babaga-3, followed by 0.040 which recorded by Salah-1. On contrast, the lowest ratio was 0.024 which obtained by both of the two hybrids of Sakha-95 with each of Rama-2 and Alshoroq-3. Meantime, the mentioned before hybrid recorded the lowest value of RWR (0.021) under water deficit germination environment, while, value of 0.040 was the highest ratio which obtained by the most superior parent Babaga-3 
SINAI Journal of Applied Sciences (ISSN: 2314-6079) Vol. (5) Is. (3), Dec., 2016

These results may reflect the impact of water stress on root cell development, which would likely impair nutrient uptake as well as having determined effects on photosynthesis, essential for biomass accumulation and therefore on shoot and root elongation (Guo et al., 2013).

\section{Chemical Analysis}

From Table 4 which pointed out to the analysis of variance under both dehydration and salinity stresses in addition to the control treatment for the tested population of bread wheat, it could be observed that there were high significant differences between, within treatments and their interactions for chemical analysis traits, except, total carbohydrates in genotypes and the interaction.

\section{Plant Pigments}

\section{Chlorophyll a content (mg g ${ }^{-1}$ FW)}

Respecting the chlorophyll a content, Fig. 13 clearly indicate that there were significant differences among genotypes and between the control and stress treatments. There was marked reduction in chlorophyll a content under both water stress and salinity conditions in all parents and their $F_{1 s}$. It could be indicated that there were insignificant differences between saline and water deficit treatments.

Records varied considerably from 1.37 to $3.43\left(\mathrm{mg} \mathrm{g}^{-1} \mathrm{FW}\right)$, from 1.16 to $2.28(\mathrm{mg}$ $\mathrm{g}^{-1} \mathrm{FW}$ ) and from 1.11 to $2.13\left(\mathrm{mg} \mathrm{g}^{-1} \mathrm{FW}\right)$ regarding to the control, polyethylene glycol and $\mathrm{NaCl}$ treatments, respectively. Whereas, lowest values recorded by Sakha-95 and the highest recorded by Babaga-3. The two hybrids Amna-2 X Damara-6 and Salah-1 $X$ Babaga-3 recorded values less than their parents concerning $F_{1}$ Performance. While, Rama-2 X Sakha -95 recorded the same value of Rama-2 and the hybrid.

Alshoroq-3 X Sakha-95 averaged its parents. The reduction in chlorophyll contents under saline soil and irrigation with underground saline water as well as solar radiation was attributed to the decrease in absorption of iron and Magnesium needed for chlorophyll synthesis (Poljakoff-Mayber and Gale, 1975). Parallel to our results, findings of Gurmani et al. (2007) and Balouchi (2010) were in harmony with our decreasing trend of chlorophyll content under stress conditions.

\section{Chlorophyll b content ( $\left.\mathrm{mg} \mathrm{g}^{-1} \mathrm{FW}\right)$}

It is evident from Fig. 14 that there were significant differences among genotypes regarding to chlorophyll $\mathrm{b}$ content $\left(\mathrm{mg} \mathrm{g}^{-1}\right.$ FW). There is no clear difference between salinity and water stress treatments, despite of the exhibited both significant and insignificant differences in a comparison with the other two comparisons. In this regard, water deficit and salinity didn't affect genotype Sakha-95 which recorded the lowest values.

Otherwise, Babaga-3 recorded the highest and significant values. Therefore, values varied from 0.22 to 1.23 , from 0.19 to 0.91 and from 0.18 to $0.81\left(\mathrm{mg} \mathrm{g}^{-1} \mathrm{FW}\right)$ under control, water deficit and salinity treatments, respectively. Values of $f_{1 s}$ were average between the values of their parents in all populations except Amna-2.

The reduced level of chlorophyll content under high salt stress condition in the leaves which may be due to membrane deterioration of the cell membrane of the chloroplastid leading towards lesser accumulation of chlorophyll and lesser photosynthetic efficiency (Seeman and Critchley, 1985). These results are in accordance with those obtained by Gurmani et al. (2007), Balouchi (2010) and Guo et al. (2013).

\section{Total Chlorophyll content ( $\mathrm{mg} \mathrm{g}^{-1} \mathrm{FW}$ )}

According to Fig. 15, there is no doubt that stress treatments affected highly significant total chlorophyll content. Therefore, water deficit decreased the range of total chlorophyll content from 1.07-3.71 under control conditions to $0.13-2.02$ (mg $\mathrm{g}^{-1} \mathrm{FW}$ ). Similar trend, salinity decreased this range considerably to $0.12-1.86\left(\mathrm{mg} \mathrm{g}^{-1}\right.$ FW). 
Battah, et al.
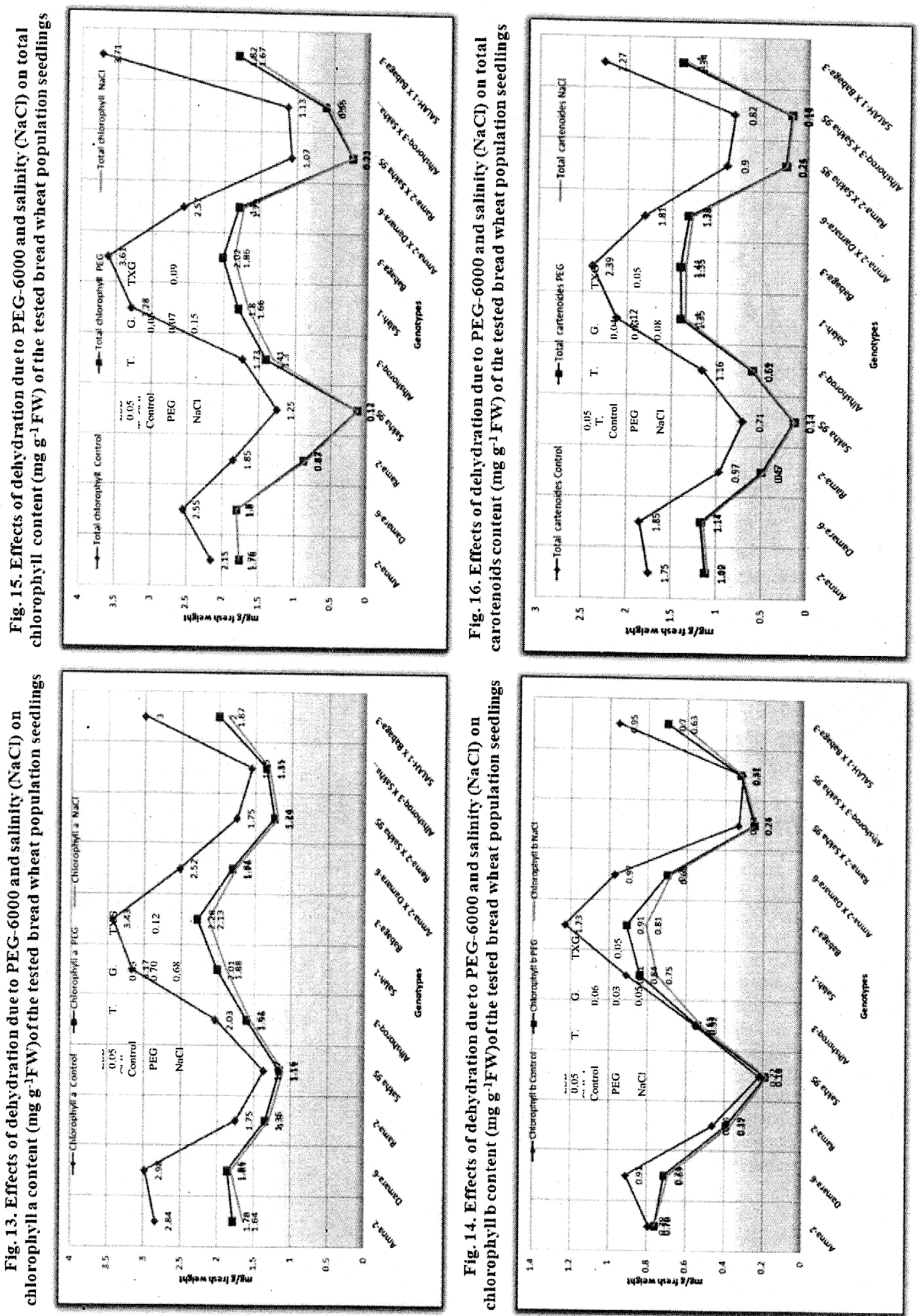
SINAI Journal of Applied Sciences (ISSN: 2314-6079) Vol. (5) Is. (3), Dec., 2016

Table (4): Analysis of variance for chemical traits ( $\mathrm{mg} \mathrm{g}^{-1} \mathrm{FW}$ ) of the tested bread wheat genotypes affected by water stress and salinity.

\begin{tabular}{|c|c|c|c|c|c|c|c|c|c|c|}
\hline \multirow[t]{2}{*}{ SOV } & \multirow[t]{2}{*}{ d.f } & \multicolumn{9}{|c|}{ Mean square } \\
\hline & & 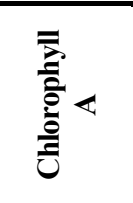 & 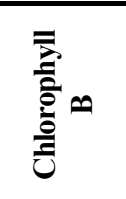 & 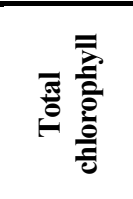 & 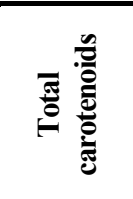 & 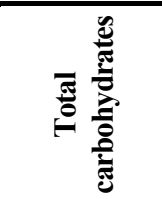 & 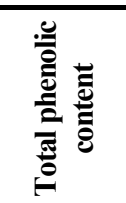 & 悹 & 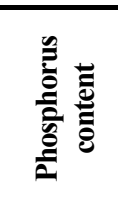 & 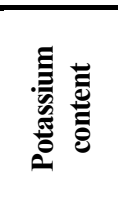 \\
\hline Treatments (T.) & 2 & $6.45^{* *}$ & $0.21^{* *}$ & $11.14^{* *}$ & $5.00^{* *}$ & $67051.24^{* *}$ & $179.87^{* *}$ & $14.31^{* * 4}$ & $2.92^{* *}$ & $10.62^{* *}$ \\
\hline Genotypes (G.) & 10 & $1.98^{* *}$ & $0.64^{* *}$ & $5.08^{* *}$ & $2.73^{* *}$ & $1088.93^{\mathrm{ns}}$ & $209.04^{* *}$ & $5.25^{* *}$ & $3.16^{* *}$ & $3.01^{* *}$ \\
\hline T. X G. & 20 & $0.17^{* *}$ & $0.02^{* *}$ & $0.28^{* *}$ & $0.03^{* *}$ & $756.20^{\text {ns }}$ & $39.09^{* *}$ & $0.46^{* *}$ & $0.15^{* *}$ & $0.03^{* *}$ \\
\hline Error & 66 & 0.003 & 0.001 & 0.003 & 0.001 & 1454.15 & 7.09 & 0.001 & 0.003 & 0.001 \\
\hline Total & 98 & & & & & & & & & \\
\hline C.V (\%) & & 2.71 & 4.65 & 3.57 & 2.93 & 42.28 & 9.01 & 0.98 & 1.68 & 1.13 \\
\hline Mean \pm STDEV & & $1.89 \pm 0.61$ & $0.60 \pm 0.27$ & $1.59 \pm 0.90$ & $1.07 \pm 0.62$ & $90.19 \pm 51.12$ & $29.57 \pm 6.15$ & $3.03 \pm 0.96$ & $3.21 \pm 0.64$ & $2.78 \pm 0.73$ \\
\hline
\end{tabular}

STDEV: standard deviation, *; significant at 0.05 level of probability, **; significant at 0.01 level of probability and ns; insignificant.
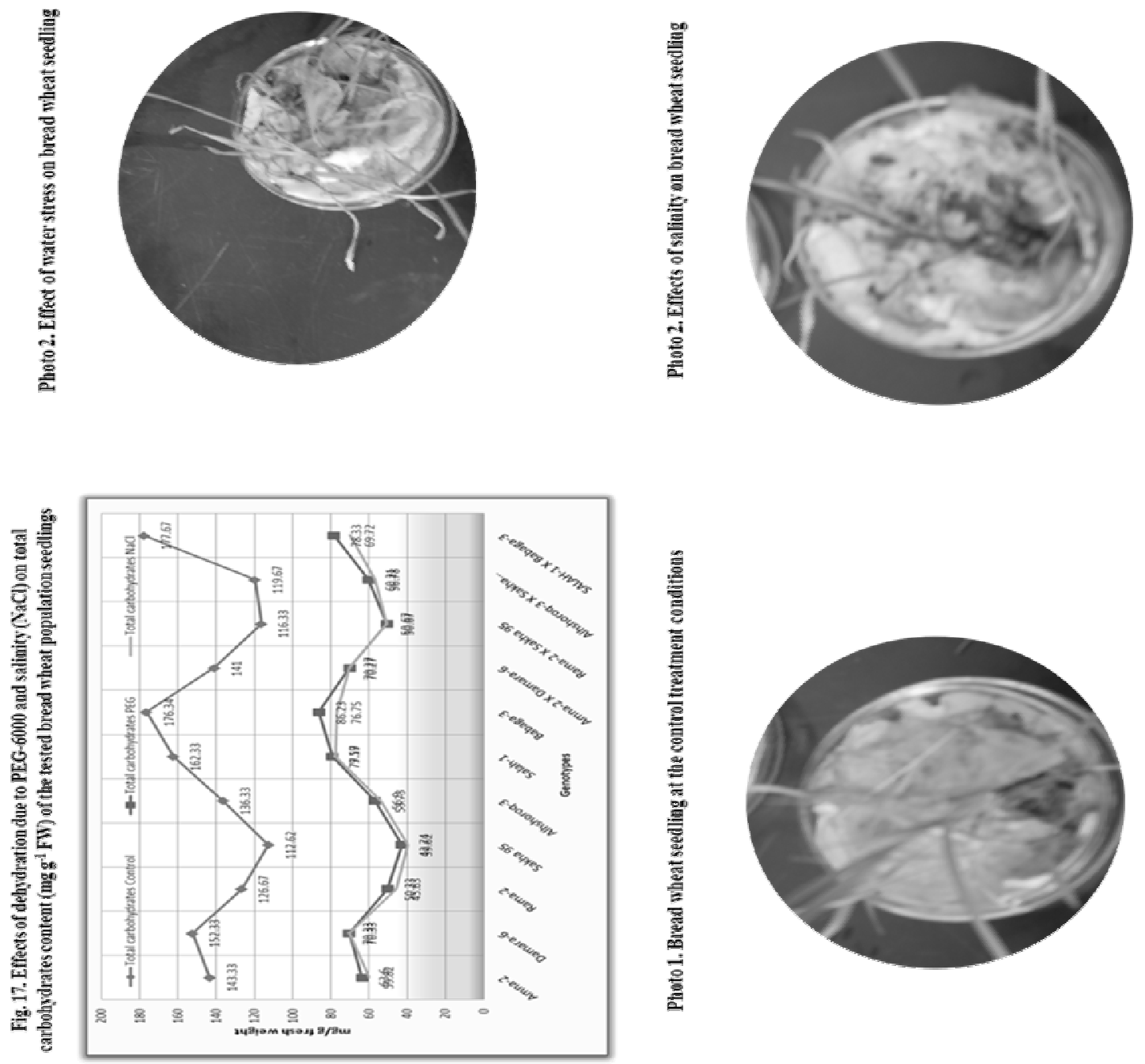

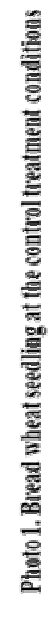

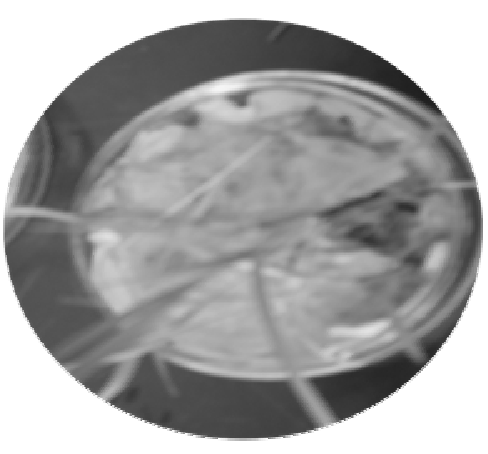


It is worthy to mention that significant between water deficit and saline stress treatments appeared only in the population of Salah-1 and Babaga-3. In addition, $F_{1 s}$ outdid their parents concerning to Amna-2 X Damara-6 and Salah-1 X Babaga-3. On contrast, both of Rama-2 X Sakha-95 and Alshoroq-3 X Sakha-95 recorded values less than those of their parents. Previously, Reddy and Vora, 1986 and Ashraf et al., 1994 related decrease in chlorophyll concentration under drought stress to the increase in activity of the chlorophyllase enzyme.

The reduction in chlorophyll contents is to be expected under stress, being membranous bound; its stability is dependent on membrane stability, which under saline condition seldom remains intact (Iqbal et al., 2006). Our results are also coping with Abdalla and ElKhoshiban (2007), Tas and Tas (2007), Balouchi (2010), Mohamed (2010) and Moaveni (2011). Data obtained by Guo et al. (2013) concerning some drought treatments caused by PEG6000 in different concentrations on bread wheat seedlings, suggested that wheat seedlings may initially sense high drought environments, the harmful effects of water stress on the distribution and carbohydrates accumulation; it was reflecting the specific detrimental effects of a drought environment. It implies that there was a closed relationship between effects of water stress on chlorophyll fluorescence parameters of wheat seedlings.

\section{Total carotenoids content $\left(\mathrm{mg} \mathrm{g}^{-1} \mathrm{FW}\right)$}

It is well appeared from Fig. 16 that total carotenoids decreased considerably as a result to both water deficit or saline water treatment. The decrease due to salinity was greater than water deficit treatment, relatively. Hence, there is no significance between the two stressed conditions. However, genotypes content of the total carotenoids differed significantly all over treatments. Values ranged from 0.71 (mg $\mathrm{g}^{-1} \mathrm{FW}$ ) by Sakha-95 to 2.39 ( $\mathrm{mg} \mathrm{g}^{-1} \mathrm{FW}$ ) by Babaga-3 under the well-watered conditions, from 0.14 to 1.41 ( $\mathrm{mg} \mathrm{g}^{-1} \mathrm{FW}$ ) recorded by the same genotypes under water deficit treatment and from 0.13 (mg $\mathrm{g}^{-1}$ FW) recorded by the most affected parent Sakha-95 to $1.35\left(\mathrm{mg} \mathrm{g}^{-1} \mathrm{FW}\right)$ by each of Salah-1 and Babaga-3 under saline environment. These results are in agreement with Tas and Tas (2007), Balouchi (2010), Mandhania et al. (2010) and Guo et al. (2013). caused by PEG6000 in different concentrations on bread wheat seedlings, suggested that wheat seedlings may initially sense high drought environments, the harmful effects of water stress on the distribution and carbohydrates accumulation; it was reflecting the specific detrimental effects of a drought environment. It implies that there was a closed relationship between effects of water stress on chlorophyll fluorescence parameters of wheat seedlings.

\section{Total Carbohydrates ( $\mathrm{mg} \mathrm{g}^{-1} \mathrm{FW}$ )}

In the respect of study the effect of water deficit stress and saline water stress on total carbohydrates content for the tested bread wheat seedlings in a comparison with their controlled environmental cultivating plants, it could be understood from Fig. 17 that there were highly significant differences due to both water stresses contrary to the control. So that wide ranges under different treatments were overestimated concerning the various responses to stress factors which exhibited considerably by the used genotypes. Thus, Sakha-95 recorded the lowest values: 112.62, 42.74 and 39.62 (mg $\mathrm{g}^{-1} \mathrm{FW}$ ) concerning control, water deficit and salinity treatments, respectively.

In this regard, the highest value under control germination was $177.67 \mathrm{mg} \mathrm{g}^{-1}$ FW) recorded by hybrid Salah-1 X Babaga3 , the highest value under water deficit conditions was $86.23\left(\mathrm{mg} \mathrm{g}^{-1} \mathrm{FW}\right)$ of the total carbohydrates content which recorded by the superior parent Babaga-3 and the 
SINAI Journal of Applied Sciences (ISSN: 2314-6079) Vol. (5) Is. (3), Dec., 2016
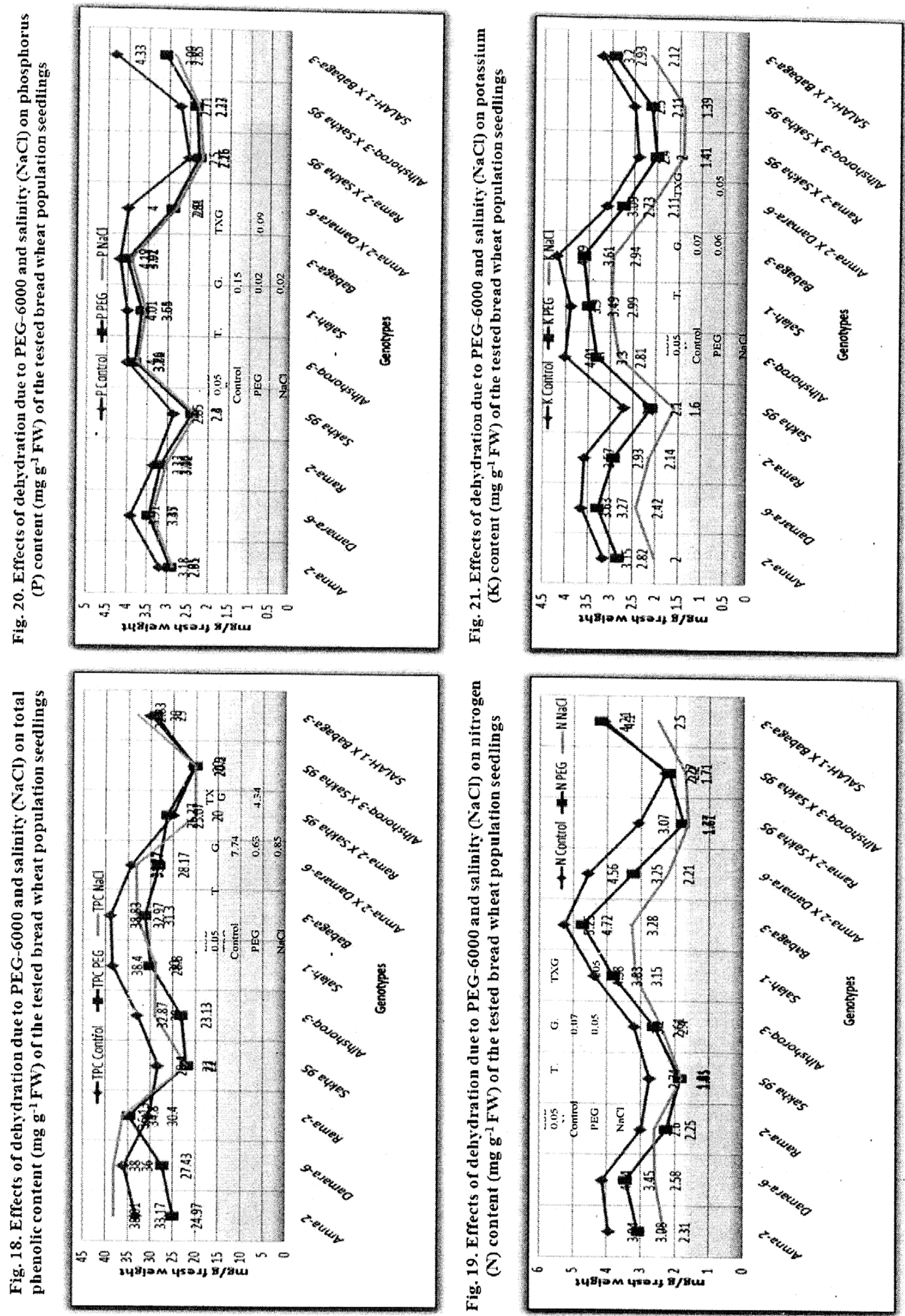
highest value under salinity treatment was $77.59\left(\mathrm{mg} \mathrm{g}^{-1} \mathrm{FW}\right)$ recorded by the another superior parent Salah-1. There were no clear significance between the water deficit stress and the saline water stress treatments. $\mathrm{F}_{1}$ Amna-2 X Damara-6 recorded a value less than those of their parents. Otherwise, Salah-1 X Babaga-3 outdid their parents. While, the 2 hybrids of Sakha-95 recorded values in the averaged of the parents.

Increment in total carbohydrates under water deficit and saline conditions may be associated with osmotic regulation of plant cells as a mechanism of salt tolerance for wheat plants. Depression effects of salinity on carbohydrates might be attributed to reduction in photosynthetic as result of chlorophyll decrease (Khafaga and AbdElnaby, 2007).

\section{Total phenolic content (TPC) $\left(\mathrm{mg} \mathrm{g}^{-1}\right.$ FW)}

From Fig. 18, it could be concluded that there was no clear indication to depend on the total phenolic contents as a selective criterion under such abiotic stresses in this study. Therefore, different responses were detection under the different three treatments. In the same time, water deficit stress and salinity water stress decreased the total phenolic content for some bread wheat genotypes and increased the total phenolic content for another some of the tested genotypes as well as the other some was not affected.

Therefore, both significant and insignificant differences have been recorded among these evaluated populations of the bread wheat plants. In view of these irregular trend, the hybrid Alshoroq-3 X Sakha-95 ranked the lowest by values of 20.39, 20.20 and 20.00 $\mathrm{mg} \mathrm{g}^{-1} \mathrm{FW}$ under the control, water deficit and salinity treatments, respectively. In addition, the hybrid Rama-2 X Sakha-95 toke placed the same rank under the salinity stress treatment.
Under the same treatment conditions, the highest values recorded $38.83,34.80$ and $38.01 \mathrm{mg} \mathrm{g}^{-1}$ FW by each of Babaga-3, Rama-2 and Amna-2, respectively. Concerning gene action studies, $F_{1 s}$ of the hybrid Amna-2x Damara under control treatment recorded an averaged value of their parents and other hybrids recorded values less than those of their parents.

\section{Nitrogen, phosphorus and potassium (NPK) contents (mg/g FW)}

Mineral nutrient components have been affected negatively, significantly and high significantly due to the two undertaken stresses of water deficit and salinity. Whereas, the exposed plants exhibited marked decrease contrary to the well quality watered plants as shown in Figures 19, 20 and 21 concerning the evaluated parents and their $F_{1}$ of bread wheat (Triticum aestinum L.) plants.

These figures are also clearly indicated that there were significant differences among genotypes and treatments. Stress effect significance was more exhibitions in latest Figure which presents potassium content under control and stresses treatments than the other two figures of the nitrogen and phosphorus.

Concerning phosphorus content, there were no significant differences between water deficit and salinity treatments. In details, water deficit decreased the lowest limit of nitrogen content under control from 2.27 to $1.77 \mathrm{mg} \mathrm{g}^{-1} \mathrm{FW}$ which recorded by the hybrid Alshoroq-3 X Sakha-95. Moreover, the highest limit from $5.25 \mathrm{mg}$ g-1 FW which recorded by the superior parent Babaga- 3 to $4.72 \mathrm{mg} \mathrm{g}^{-1} \mathrm{FW}$ which recorded by the same superior parent (Fig. 19).

Water shortage stress also decreased the lowest level of phosphorus content under control treatment from $2.50 \mathrm{mg} \mathrm{g}^{-1} \mathrm{FW}$ which recorded by the hybrid Rama-2 $\mathrm{X}$ Sakha-95 to $2.26 \mathrm{mg} \mathrm{g}^{-1}$ FW. Likewise, the highest content was decreased from 4.33 to 
$2.85 \mathrm{mg} \mathrm{g}^{-1} \mathrm{FW}$ which recorded by the superior hybrid Salah-1 X Babaga-3. Similarly, the hybrid Rama-2 X Sakha-95 and the superior parent Babaga-3 exhibited the lowest and the highest content of potassium, respectively. Thus, water shortage stress decreased potassium content from 2.40 to 2.00 and 4.19 to $3.61 \mathrm{mg} \mathrm{g}^{-1} \mathrm{FW}$ regarding to the lowest and the highest limits, respectively.

In this respect and concerning saline water stress, it could be noticed that salinity decreased the lowest limit of nitrogen to $1.61 \mathrm{mg} \mathrm{g}^{-1} \mathrm{FW}$ which recorded by the hybrid Rama-2 X Sakha-95 and the highest limit to $3.28 \mathrm{mg} \mathrm{g}^{-1} \mathrm{FW}$ which recorded by the superior parent Babaga-3 (Fig. 19).

Moreover, salinity decreased the range of phosphorus significantly to $2.16-3.91 \mathrm{mg}$ $\mathrm{g}^{-1} \quad$ FW which obtained by the abovementioned two genotypes, respectively. Similar trend, range of potassium content was reduced significantly due to salinity stress to $1.39-2.94 \mathrm{mg} \mathrm{g}^{-1} \mathrm{FW}$, since the lowest value obtained by the hybrid Alshoroq-3 X Sakha-95 and the highest value was obtained by the superior parent Babaga-3 (Fig. 21).

On the other hand, for gene action, firstly Amna-2x Sakha-95 outdid its parents concerning $\mathrm{N}$ and $\mathrm{P}$ content, while it recorded value less than those which recorded by its parents concerning K content. Secondly, Rama-2 X Sakha-95 recorded values greater than those which obtained by each of the two parents Rama-2 and Sakha-95 concerning $\mathrm{N}$ content contrary to the results of both $\mathrm{P}$ and $\mathrm{K}$ contents. Thirdly, Alshoroq-3 X Sakha-95 recorded value less than those which obtained by its parents for all NPK contents.

Fourthly, Salah-1 X Babaga-3 outdid its parents concerning $\mathrm{N}$ and $\mathrm{P}$ contents contrary the $\mathrm{K}$ content which gave values less than those of its parents. Water stress can reduce NPK content, this reduction might occur due to water deficit induced reduction in transpiration rate and stomatal conductance (Pessarakli, 1999; Ali et al., 2007). Janardan et al. (1976) reported that $\mathrm{K}$ plays a role in raising salt tolerance of wheat crops. Sodium competes with $\mathrm{K}^{+}$for uptake through common transport system and dose this effectively since the $\mathrm{Na}^{+}$ concentration in saline environments is usually considerably greater than that of $\mathrm{K}^{+}$. Sensitivity of some crops to salinity is due to the inability to keep $\mathrm{Na}^{+}$and $\mathrm{Cl}^{-}$out of transpiration streams (Munns et al., 2002).

The decrease in $\mathrm{K}$ is due to the presence of excessive $\mathrm{Na}^{+}$in the growth medium because high external $\mathrm{Na}$ content is known to have an antagonistic effect on $\mathrm{K}$ uptake in plant, since; salt tolerance is associated with $\mathrm{K}$ content because of its involvement in osmotic regulation and competition with $\mathrm{Na}$.

Furthermore, regulation of $\mathrm{K}$ uptake, prerention of $\mathrm{Na}$ entry and efflux of $\mathrm{Na}$ from cell are the strategies commonly used by plants to maintain desirable $\mathrm{K} / \mathrm{Na}$ ratio in the cytosol (Sarwar and Ashraf, 2003). While, Abdelsalam (2012) reported that all wheat genotypes in his study showed decreasing trend in $\mathrm{K}$ content due to salinity stress.

\section{Acknowledgment}

We wish to express our greatest and sincerest gratitude to ALLAH the Almighty, Beneficent and Merciful God. It is a honor and pleasure to acknowledge here Dr. Dina Abd Al-Aty Soliman lecturer of Floriculture, Medicinal and Aromatic Plants, Department of Plant Production, Faculty of Environmental Agricultural Science, Al-Arish University for her cooperation, advices and assistances in the chemical analysis and laboratory procedures.

\section{Conclusion}

Our current breeding program is still continual, program needs mainly such this 
evaluating study just before decide, which may support our understanding of the genetic behavior under stressed conditions for different mechanisms stand against. Logically, stress was negatively affected the studied characters. Nevertheless, observations led to high genetic gain, since, the phenotypic variance reflects clearly the genotypic variance under the same environmental conditions. Consequently, In the future, we expect not only accepted hybrids but also epistatic varieties.

\section{REFERENCES}

Abdalla, M.M. and El-Khoshiban, N.M. (2007). The influence of water stress on growth, relative water content, photosynthetic pigments, some metabolic and hormonal contents of two Triticum aestivum cultivars. J. App. Sci. Res., 3 (12): 2062-2074.

Abdelsalam, N.R. (2012). Screening for salt tolerance in common and relatives wheat via multiple parameters. Res. J. Agric. and Biological Sci., 8 (1): 36-44.

Abdoli, M.; Saeidi, M.; Jalali-Honarmand, S.; Mansourifar, S. and EghbalGhobadi, M. E. (2013). Evaluation of some physiological and biochemical traits and their relationships with yield and its components in some improved wheat cultivars under post-anthesis wheat deficit environmental stress. Crop Sci., 6(1): 47-63.

Afzal, I.; Basra, S.M.A.; Hameed, A. and Farooq, M. (2006). Physiological enhancements for alleviation of salt stress in wheat. Pak. J. Bot., 38 (5): 1649 - 1659.

Ahmed, A.; Uptmoor, R.; El-Morshidy, M. A.; Kheiralla, K.A.; Ali, M.A. and Mohamed, N.E.M. (2014). Some physiological parameters as screening tools for drought tolerance in bread wheat (Triticum aestivum L.) lines. World J. Agric. Res., 2 (3): 109-114.
Akram, M. (2011). Growth and yield components of wheat under water stress of different growth stages. Bangladesh J. Agri. Res., 36 (3): 455-468.

Alam, A.M.S.; Kabir, G.; UD-Deen, M.M. and Hoque, E. (2011). Effect of water stress on stomatal characters of tuenty one near isogenic lines of wheat (Triticum aestivum). Bangladech J. Agric. Res., $36: 1$.

Ali, Q.; Ashraf, M. and Athar, H.R. (2007). Exogenously applied proline at different growth stages enhances growth of two maize cultivars grown under water deficit conditions. Pak. J. Bot., 39 (4): 1133-1144.

Ashraf, M.Y.; Azmi, A.R.; Khan, A.H. and Ala, S.A. (1994). Effect of water stress on total phenol, peroxidase activity and chlorophyll contents in wheat. Acta physiol. Plant, 16 (3): 185191.

Assadian, N.W. and Miyamoto, S. (1987). Salt effects on alfalfa seedling emergence. Agron. J., 79: 710-714.

Bakalova, S.A.; Nikolova, D. and Nedeva, B. (2004). Isoenzyme profiles of peroxidase, catalase and superoxide dismutase as affected by dehydration stress and aba during germination of wheat seeds. J. Plant Physiol., 30 (1-2): 64-77.

Balouchi, H.R. (2010). Screening Wheat Parents of Mapping Population for Heat and Drought Tolerance Detection of Wheat Genetic Variation. World Acad. Sci., Eng. and Technol., 662010.

Battah, M.S. (2014). Genetical and biotechnological studies on some bread wheat lines. Ph.D. Thesis, Plant Prod., Fac. Env. Agr. Sci., Suez Canal Univ.

Beers, R.F.Jr. and Sizer, I.W. (1952). A spectrophotometeric method for measuring the breakdown of hydrogen peroxide by catalase. J. Biol. Chemist., 195; 33-35. 
Beta, T.; Nam, S.; Dexter, J.E. and Sapirstein, H.D. (2005). Phenolic content and antioxidant activity of pearled wheat and roller-milled fractions. Cearal Chem., 82: 390-393.

Chang, S.M. and Sung, J.M. (1998). Deteriorative changes in primed sweet corn seeds during storage. Seed Sci. Technol., 26: 613-626.

Chapman, H.D. and Partt, P.E. (1961). Method of soil, plants and water analysis. Univ. California, Div. Agric. Sci.

Chaves, M.M.; Flexas, J. and Pinheiro, C. (2009). Photosynthesis under drought and salt stress: regulation mechanisms from whole plant to cell. Ann. Bot., 103: 551-560.

Chetti, M.B. and Sirohi, G.S. (1995). Effect of water stress on leaf characteristics and its recovery in mung bean (Vigna radiata L.), Wilczek cultivars. J. Maharashtra Agric. Univ., 20 (3): $85-87$

Chiu, K.Y.; Wang, C.S. and Sung, J.M. (1995). Lipid peroxidation and peroxidescavenging enzymes associated with accelerated aging and hydration of watermelon seeds differing in ploidy. Physiologia plantarum, 94:441-446.

Cornic, G. (2000). Drought stress inhibits photosynthesis by decreasing stomatal aperture, not by affecting ATP synthesis. Trends plant Sci., 5: 187-188.

Csiszar, J.; Feher-Juhasz, E.; Kotai, E.; IvankovitsKiss, O.; Horvath, G. V.; Mai, A.; Galle, A.; Tari, I.; Pauk, J.; Dudits, D. and Erdei, L. (2005). Effect of osmotic stress on antioxidant enzyme activities in transgenic wheat calli bearing MsALR gene. Acta biologica szegediensis, 49: 49-50.

Datta, J.K.; Nag, S.; Banerjes, A. and Mondal, N.K. (2009). Impact of Sole stress on Five Variances of Wheat
(Triticum aestivum L.) Cultivars under Laboratory Conditions. J. Appl. Sci. Environ. Manag., 13 (3): 93-97.

Davies, W.J. and Zhang, J. (1991). Root signals and the regulation of growth and development of plants in drying soil. Ann. Rev. plant Physiol. Plant Mol. Biol., 42: 55-76.

De Souza, A.; Garcia, D.L.; Licea, S.L. and Porras, E. (2005). Pre-sowing magnetic treatment of tomato seeds: Effects on the growth and yield of plants cultivated late in the season. Spanish J. Agric. Res., 3: 113-122.

Du, Y. and Huang, Z.I. (2008). Effects of seed mass and emergence timr on seedling performance in Castanopsis chinensis. Forest ecology and management. 255: 2495-2501.

El-Sarag, E.I.; Battah, M.S. and Hassan H.M.S. (2015). In vitro heterosis for osmotic relative tolerance in wheat. CATRINA, by the $6^{\text {th }}$ Int. Con. Egyp. Soci. Environ. Sci., Ismailia, $2^{\text {nd }}-4^{\text {th }}$ Feb., 14 (1): 77-93

Fahad, S.; Hussain, S.; Saud, S.; Hassan, S.; Tanveer, M.; and Ihsan, M.Z. (2016). A combined application of biochar and phosphorus alleviates heatinduced adversities on physiological, agronomical and quality attributes of rice. Plant Physiol. Biochem., 103: 191198.

Finkeistein, R.R.; Gampala, S.S. and Rock, C.D. (2002). Abscisic acid signaling in seeds and seedlings. Plant cell, 14: $15-45$.

Gao, L.; Wang, S.; Oomah, B.D. and Mazza, G. (2002). Wheat quality: Antioxidant activity of wheat millstreams. In Wheat Quality Elucidation; Ng, P., Wrigley, C.W., Eds.; AACC Int., St. Paul, MN, 219-233.

Gollan, T.; Schurr, U. and Schulze, E.D. (1992). Stomatal response to soil drying 
in relation to changes in the xylem sap composition of Helianthus annuus: II. Stomatal sensitivity to abscisic acid imported from the xylem sap. Plant cell Environ., 15: 561-567.

Guendouz, A.; Seemcheddine, N.; Moumeni, L. and Hafsi, M. (2016). The effect of supplementary irrigation on leaf area, specific leaf weight, grain yield and water use efficiency in durum wheat (Triticum durum Desf.). Ekin. J. crop Breed. Gen., 2 (1): 82-89.

Guo, R.; Hao, W.P.; Gong, D. Z.; Zhong, X.L. and Gu, F.X. (2013). Effects of water stress on germination and growth of wheat photosynthetic efficiency and accumulation of metabolites. Intech, soil processes and current trends in quality assessment, chapter 13: 367-380. http:// dx. doi.org/10.5772/5/205.

Gurmani, A.R.; Bano, A. and Salim, M. (2007). Effect of abscisic acid and 6benzyladenine on growth and ion accumulation of wheat under salinity stress. Pak. J. Bot., 39 (1): 141-149.

Hajiboland, R. (2014). Reactive oxygen species and photosynthesis, oxidative damage to plants, antioxidant networks and signaling. Acad. Press, 1-63.

Hajiboland, R.; Sadeghzadeh, N. and Sadeghzadeh, B. (2014). Effect of Se application on photosynthesis, osmolytes and water relations in two durum wheat (Triticum durum) genotypes under drought stress. Acta Agric. Sloven., 103 (2): 167-179.

Herbert, D.; Philips, P.J. and Strange, R.E. (1971). Determination of total carbohydrates. Methods in Microbiol., 58: 209-344.

Hong, B. and Bary, R. (1992). Developmental and organ-specific expression of an ABA and stressinduced protein in barley. Plant Molecular Biol., 18: 663-674.
Hsiao, T.C. (1973). Plant responses to water stress. Annu. Rev. Plant Physiol., 24: 519-570.

Ihsan, M.Z.; El-Nakhlawy, F.S.; Ismail, S.M.; Fahad, S. and Daur, I. (2016). Wheat phenological development and growth studies as affected by drought and late season high temperature under arid environment. Front. Plant Sci. http://doi.org/10.3589/fpls.2/100795.

Iqbal, M.; Ashraf, M. and Gamil, A. (2006). Seed enhancement with cytokinins: change in growth and grain yield in salt stressed wheat plants. Plant Growth Regulation, 50: 29-39.

Jackson, M.L. (1973). Soil chemical analysis. New Delhi, India: prentice hall of India. $1^{\text {st }}$ Ed., 521.

Janardan, K.V.; Murtay, K. and Girira, J. (1976). Salt tolerance of cotton and potential use of saline water for irrigation. J. Curr. Sci., 45: 334-336.

Jiao, S.Y.; Li, Y.O.; Shayila, S. H. and Chen, X.L. (2009). Seeds germination and seedling growth about 3 Pennisetum ornamental grasses under drought stress. Acta Bot. Boreal. Occident. Sin., 29 (2): 308-313.

Jones, M.M. and Turner, N.C. (1978). Osmotic adjustment in leaves of sorghum in response to water deficits. Plant Physiol., 61: 122-126.

Kayani, S.A.; Naqvi, H.H. and Ting, I.P. (1990). Salinity effects on germination and mobilization of reserves in Jojoba seed. Crop Sci., 30 (3):704-708

Keyvan, S. (2010). The effects of drought stress on yield, relative water content, proline, soluble carbohydrates and chlorophyll of bread wheat cultivars. J. Anim. Plant Sci. 8(3): 1051- 1060.

Khafaga, H.S. and Abd-EInaby, A.S. (2007). Physiological studies on the adaptation of some wheat varieties under 
El-Wady El-Gedid conditions. Afri. Crop

Sci. Conf. Proc. 8:2047-2055, printed in El-Minia, Egypt by Afri. Sci. Soci.

Khan, D.; Shaukat, S.S. and Faheemuddin, M. (1984). Germination studies of certain plants. Pak. J. Bot., 16: 231-254.

Khan, H.R.; Paull, J.G.; Siddique, K.H.M. and Stoddard, F.L. (2010). Faba bean breeding for drought-affected environments: a physiological and agronomic perspective. Field crop Res., 115: 279-286.

Lagerwerff, J.V.; Ogata, G. and Eagle, H.E. (1961). Control of osmotic pressure of culture solutions with polyethylene glycol. Sci., 133: 1486-1487.

Liley, J.M. and Ludlow, M.M. (1996). Expression of osmotic adjustment and dehydration tolerance in disease rice lines. Field crop Res., 48: 185-197.

Lochtenthaler, H.K. (1987). Method. Enzymol. 148: 350-382.

Ma, H.Y. and Liang, Z.W. (2005). Research progress on improving germination rate of Leymus chinensis. Grassland of China, 27 (4): 64-68.

Mandhania, S.; Madan, S. and Sheokand, S. (2010). Differential responses in salt tolerance and sensitive genotypes of wheat in terms of Ascorbate, Carotenoids, Proline and Plant Water relations. Asian J. Exp. Biol. Sci., 1(4): 792-797.

Meiri, A. and Poljakoff-Mayber, A. (1970). Effect of various salinity regimes on growth, leaf expersions and transpiration rate of bean plants. Plant Soil Sci., 109: 26-34.

Mer, R.K.; Prajith, P.K.; Pandya, D.H. and Pandey, A.N. (2000). Effect of salts on germination of seeds and growth of young plants of Hordeum vulgare, Triticum aestivum Cicer arietinum and Brassica juncea. J. Agron. And crop Sci., 185: 209-217.
Michel B.E. and Kaufmann, M.R. (1973). The osmotic potential of polyethylene glycol 6000. Plant Physiol., 51: 914-916.

Moaveni, P. (2011). Effect of water deficit stress on some physiological traits of wheat (Triticum aestivum). Agric. Sci. Res. J., 1 (1): 64-68.

Mohamed, M.A. (2010). Water requirement of some wheat cultivars under sandy soil conditions. M. Sc. Thesis, Arid Land Agric. Grad. Stud. Res. Inst., Fac. Agric., Ain Shams Univ.

Mohammady, S.; Khazaei, H. and Raeisi, F. (2006). The study of stomatal characteristics in Iranian wheat wild accession and land races. Wheat information Ser. Elect. Newsl. for wheat Res. Available at:. http://www.shigen. aig.ac.jp/ewis/index.isp.

Morgan, J.M. (1984). Osmoregulation and water stress in higher plants. Annu. Rev. Plant Phys., 35: 299-319.

Munns, R. and Tester, M. (2008). Mechanisms of salinity tolerance Ann. Rev. Plant Biol., 59:651-681

Munns, R.; Goyal, S.S. and Passioura, J. (2011). Salinity stress and its mitigation. http://www.plantstress.com.

Munns, R.; Husain, S.; Rivelli, A.R.; James, R.A.; Condon, A.G.; Lindsay, M.P.; Lagudah, E.S.; Schachtman, D.P. and Hare, R.A. (2002). Avenues for increasing salt tolerance of crops, and the role of physiologically based selection traits. Plant Soil, 247: 93-105.

Murungu, F.S. (2011). Effects of seed priming and water potential on seed germination and emergence of wheat (Triticum aestivum L.) varieties in laboratory assays and in the field Afr. J. Biotechnol., 10 (21): 4365-4371.

Ozalkan, C.; Sepetolu, H.T.; Daur, I. and En, O.F. (2010). Relationship between some plant groeth parameters and grain 
yield of chickpea (Cicer arietinum L.) during different growth stages. Turk. J. Field Crops, 15(1): 79-83.

Peach, K. and Tracy, M.V. (1956). Modern methods of plant analysis. Springer-Verlag Berlin, 4 (1): 643.

Pennypacker, B.W.; Leath, K.T.; Stout, W.L. and Hill, J.R. (1990). Technique for simulating field drought stress in the green house. Agron. J., 82(5); 951-957.

Pessarakli, M. (1999). Handbook of plant and crop stress. $2^{\text {nd }}$ Ed., Tucson Arizona Univ., USA.

Poljakoff-Mayber, A. and Gale, J. (1975). Plants in Saline Environments. SpringerVerlag, Berlin, Heidelberg. $1^{\text {st }}$ Ed., (15): 216.

Premachandra, O.S.H.; Saneoka, H. and Ogata, S. (1994). Cell membrane stability an indicator of drought tolerance as affecet by applied nitrogen in soyabean. J. Agric. Sci. (Camb), 115: 63-66.

Rahman, M. and Kayani, S.A. (1988). Effects of chloride type of salinity on root growth and anatomy of corn (Zea mays L.). Biol., 34 (1): 123-131.

Rahman, M.; Soomro, U.A.; Hag, M.Z. and Gul, S. (2008). Effects of $\mathrm{NaCl}$ salinity on wheat (Triticum aestivum L.) cultivars. World J. Agric. Sci., 4 (3): 398- 403.

Rascio, A.; Cedola, M.; Topani, M.; Flagella, Z. and Wittmerm G. (1990). Leaf morphology and water status changes in Triticum durum under water stress. Physiol. Plant, 78: 462-467.

Reddy, M.P. and Vora, A.B. (1986). Changes in pigment composition, Hill reaction activity and saccharides metabolism in Bajra (Pennisetum typhoides $\mathrm{S}$ and $\mathrm{H}$ ) leaves under $\mathrm{NaCl}$ salinity. Photosynthetica, 20: 50-55.
Redman, R.E. (1974). Osmotic and specific ion effects on the germination of alfalfa. Canadian J. Bot., 52: 803-808.

Ross, M.A. and Harper, J.L. (1972). Occupation of biological space during seedling establishment. J. Ecol., 60: 7088.

Saeidi, M.; Ardalani, S.; Jalali-Honarmand, S.; Ghobadi, M. and Abdoli, M. (2015). Evaluation of drought stress at different bread wheat cultivars. Acta biologica szegediensis, 55 (1): 35-44. http://www.Sci.u.szeged.hu/ABS.

Saeidi, M.; Moradi, F.; Ahmadi, A.; Spehri, R.; Najafan, G. and Shabani, A. (2010). The effects of terminal water stress on physiological characteristics and sink-soure relations in two bread wheat (Triticum aestivum L.) cultivars. Iran J. Crop Sci., 12 (4): 392-408.

Sairam, R.K. (1994). Effect of moisture stress on physiological activities of two contrasting wheat genotypes. Ind. J. Exp. Biol. M., 32: 593-594.

Sari, L.; Purwito, A.; Soepandi, D.; Purnamaningsih, R. and Sudarmonowati, E. (2015). The morphology, anatomy and physiology characterization of mutant wheat (Triticum aestivum L.) "Alibey" in tropical lowland area. J. Bio. and Env. Sci., 6 (1): 395-403.

Sarwar, G. and Ashraf, M.Y. (2003). Genetic variability of some primitive bread wheat varieties to salt tolerance. Pak. J. Bot., 35: 771-777.

Seeman, J.R. and Critchley, C. (1985). Effects of salt stress on growth, ion content, stomatal behavior and photosynthetic capacity of salt sensitive species Phaseolus vulgaris L. Planta, 164: 151-162.

Sharma, M.L. (1973). Simulation of drought and its effect on germination of five pasture species. Agron. J., 65: 982987. 
Sharma, P.K.; Sankhalkar, S. and Fermandes, Y. (2002). Possible function of ABA in protection against photodamage by stimulating xanthophyll cycle in sorghum seedlings. Curr. Sci. 82: $167-171$

Shen, L.M.; David, M. and Joyee, G.F. (1990). Influence of drought on the concentration and distribution of 2,4diaminaobutyric acid and other free amino acids in tissues of flat pen (Lathyrus sylvestris L.). Environ. Expt. Bot., 30: 497-504.

Shi, G.Y.; Liao, W.X.; Qin, L.F. and Lu, L.L. (2009). PEG simulated water stress effects on physiological and biochemistry indexes of germination of Toona sinensis seeds. J. Forestry Sci. and Tech., 4: 142145 .

Shi, Z.; Shi, S.Q.; Xiao, W.F. and Qi, L.W. (2008). Influence of dehydration on characteristics of chlorophyll fluorescence of detached leaves in Haloxylon ammodendron and Populus euphratica. Forest Res., 21(4): 566-570.

Singh, B.D. (1993). Plant breeding: principles and methods. Kolyani publishers, Ludhiana, India, 896.

Singh, P.; Ibrahim, H.M.; Flury, M.; Schillinger, W.F. and Knappenberger, T. (2013). Critical water potentials for germination of wheat cultivars in the dryland Northwest USA. Seed Sci. Res., 23: 189-198.

Singleton, U.L. and Rossi, J. (1965). Colorimetry of total phenolics with phosphomolybdic-posphotungustic and reagent. Ann. J. Enol. Vit., 16: 144.

Steel, R.G.D. and Torrie, T.H. (1980). Principles and procedures of statistics Mc Graw-Hill. Int. Book Company $3^{\text {rd }}$ Ed. London, 633.

Tas, S. and Tas, B. (2007). Some physiological responses of drought stress in wheat genotypes with different ploidity in Turkiye. World J. Agri. Sci., 3 (2): 178-183.

Tezara, W.; Martinez, D.; Rengifo, E. and Herrera, A. (2003). Photosynthetic response of the tropical spiny shrub Lycium nodosum (Solanaceae) to drought, soil salinity and salin spray. Ann. Bot., 92: 757-765.

Thompson, D.S.; Wilkinson, S.; Bacon, M.A. and Davies, W.J. (1997). Multiple signals and mechanisms that regulate leaf growth and stomatal behavior during water deficit. Physiol. Plant, 100: 303-313.

Tingey, D.T. and Stockwell, C. (1977). Semipermeable membrane system for subjecting plants to water stress. Plant Physiol., 60: 58-60.

Unyayar, V.; Keles, C. and Unal, E. (2004). Proline and ABA levels in two sunflower genotypes subjected to water stress. Bulgian J. Plant Physiol., 30 : 34-47

USDA (2015). United States Department of Agriculture. World Agricultural Supply and Demand Estimates. Available on line at: http://www.usda.gov/oce/ commodity/wasde/latest.

Verslues, P.E.; Ober, E.S. and Sharp, R.E. (1998). Root growth and oxygen relation at low water potentials impact of oxygen availability in polyethylene glycol solution. Plant Physiol., 116: 1403 - 1412.

Wang, J.G.; Chen, G.C. and Zhang, C.L. (2002). The effects of water stress on soluble protein content, the activity of SOD, POD and CAT of two ecotypes of reeds (Phragmi tescommunis). Acta Bot. Boreal. Occident. Sin., 22(3): 561-565.

Wang, R.; Bai, Y. and Tanino, K. (2005). Germination of winterfat (Eurotia lanata (Pursh) Moq.) seeds at reduced water potentials: testing assumptions of hydrothermal time model. Environ. and Exp. Bot., 53:49-63 
Watanabe, N.; Fujii, C.; Shiroto, M. and

Furuta, Y. (1991). Changes in chlorophyll, thylakoid protein and photothynthetic adaptation to sun and shade environment in diploid and tetraploid Oryza punctuate Kotschy and diploid Oryza eichingeri Peter. Plant Phys. Bioch. Paris, 31(4): 469-474.

Watson, D.J. (1952). The physiological basis of variation in yield. Advances in Agron. Academic press Inc., New York, (4): 101-144.

Williams, J. and Shaykewich, C.E. (1969). An evaluation of polyethylene glycol PEG 6000 and PEG 20000 in the osmotic control of soil water matric potential. Canad. J. soil Sci., 49: 397-401.
Yang, X.Q.; Zhang, S.Q.; Liang, Z.S. and Shan, Y. (2004). Effects of water stress on chlorophyll fluorescence parameters of different resistance waiter wheat cultivars seedlings. Acta Bot. Boreal. Occident. Sin., 24: 812-816.

Yoshiba, Y.; Kiyosue, T.; Nakashima, K.; Shinozaki, K.Y. and Shinozaki, K. (1997). Regulation of levels of proline as an osmolyte in plants under water stress. Plant cell Phys., 38 (10): 1095-1102.

Zhu, J.K. (2003). Regulation of ion hormeostasis under salt stress. Curr. Opin. Plant Biol., 6 (5): 441-445.

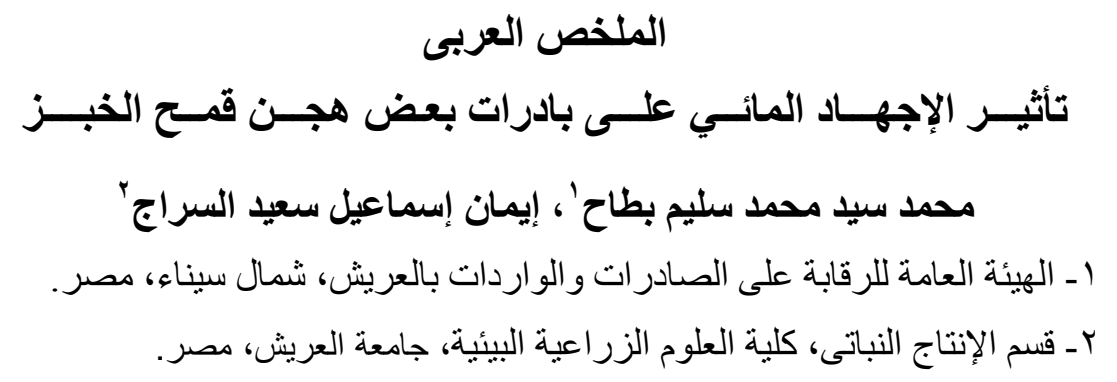

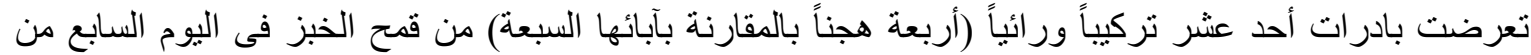

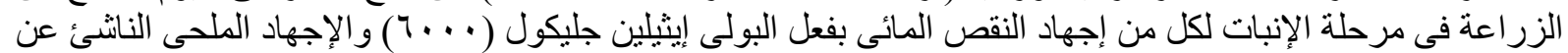

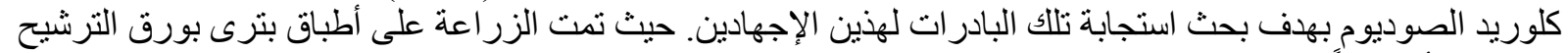

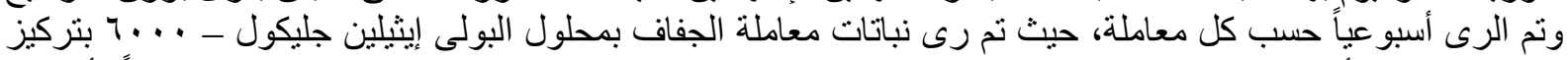

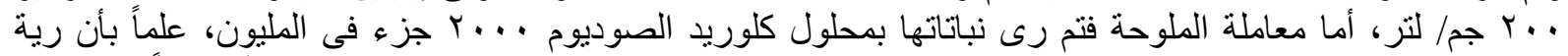

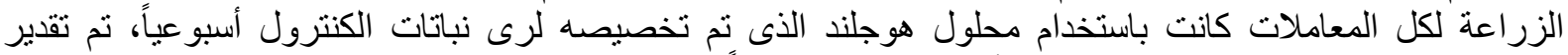

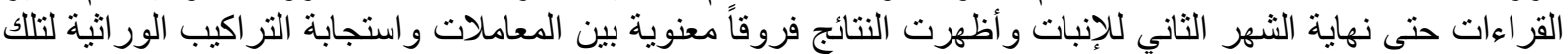

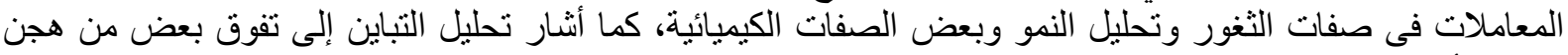
الجيل الأول فى قدرتها على تحمل الظروف غير الملائمة للانبات من حيث الجفاف و الملوحة. الكلمات الاسترشادية: قمح الخبز، مرحلة إنبات البادرات، الإجهاد المائى، الملوحة، تحليل النمو، هجن الجيل الجيل الأول.

أستاذ المحاصيل المتفرغ، كلية الزر اعة، جامعة الزقازيق، مصر.

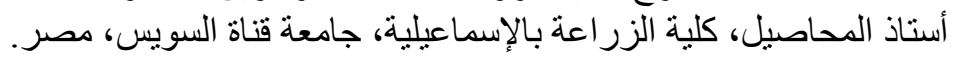

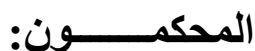

ا ـ أ.د. عبد الستار عبد القادر الخواجة

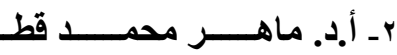

